\title{
Delivering SiRNA with Dendrimers: In Vivo Applications
}

\section{Victoria Leiro',2,\#, Sofia Duque Santos ${ }^{1,2, \#}$ and Ana Paula Pêgo ${ }^{1,2,3, *}$}

${ }^{1}$ Instituto de Investigação e Inovação em Saúde (i3S), Universidade do Porto, Porto, Portugal; 2Instituto de Engenharia Biomédica (INEB), Universidade do Porto, Porto, Portugal; CInstituto de Ciências Biomédicas Abel Salazar (ICBAS), Universidade do Porto, Porto, Portugal; dFaculdade de Engenharia (FEUP), Universidade do Porto, Porto, Portugal

*Address correspondence to this author at the nBTT Group, Instituto de Investigação e Inovação em Saúde (i3S), Universidade do Porto, Rua Alfredo Allen, 208, 4200-135 Porto, Portugal; Tel: +351 220 408 80o;E-mails: apego@izs.up.pt; apego@ineb.up.pt, \#Equal contribution.

Originally published in: Current Gene Therapy. 2017;17(2):105-19

"The published manuscript is available at EurekaSelect via http://www.eurekaselect.com/openurl/content.php?genre=article\&doi=10.2174/1566523217666170 510160527."

\section{ABSTRACT}

Background: Over the last decades, gene therapy has emerged as a pioneering therapeutic approach to treat or prevent several diseases. Among the explored strategies, the short-term silencing of protein coding genes mediated by siRNAs has a good therapeutic potential in a clinical setting.

Material \& Methods: However, the widespread use of siRNA will require the development of clinically suitable, safe and effective vehicles with the ability to complex and deliver siRNA into target cells with minimal toxicity. Lately, dendrimers have gained considerable attention as non-viral vectors in nucleic acid delivery due to their unique structural characteristics (globular, well defined and highly branched structure, multivalency, low polydispersity and tunable nanosize), along with their relevant capacity to complex and protect nucleic acids in compact nanostructures, which can be functionalized with targeting moieties in order to get cell specificity.

Conclusion: Here, we present an overview of the state-of-the-art of the most significant and recent advances on the use of dendrimers as siRNA delivery vectors, with particular focus on the in vivo applications. We will cover the use of different dendrimers, distinct administration routes, toxicity issues, as well as the target tissue or disease, highlighting the potential of dendrimers as nanocarriers for therapeutic and biomedical applications.

Keywords: Dendrimers, RNAi, siRNA, Gene therapy, In vivo, Nanomedicine, Nanoparticles, Biodistribution. 


\section{INTRODUCTION}

\subsection{RNA Interference (RNAi)}

In 1998, an unforeseen gene-silencing event in nematodes [1], later called RNA interference (RNAi), was discovered. Further investigations confirmed that a similar response also existed in mammalian cells [2]. Briefly, RNAi is a post-transcriptional regulatory mechanism that consists of the cleavage, by an endonuclease called Dicer [3], of endogenous long double stranded RNA (dsRNA) molecules into small interfering RNAs of about 21-23 nucleotides that are incorporated into the RNA-Induced Silencing Complex (RISC). After, RNA helicases unwind the double-stranded siRNA and the antisense strand guides RISC to the complementary messenger RNA (mRNA) for degradation. RNAi can be mimicked by synthetic RNA molecules, such as micro RNA (miRNA), short hairpin RNA (shRNA) and small interference RNA (siRNA). The latter mediates gene silencing by inducing sequence-specific cleavage of targeted mRNA in a catalytic process [4-6] (Fig. 1).

Quickly, it was appreciated the potential of RNAi-based therapies for down-regulating abnormal gene expression or mutated proteins involved in some human diseases that are not targetable by conventional drugs. Among the strategies for turning off protein expression, RNAi mediated by synthetic siRNAs has a good potential in a clinical setting for the exploration of new therapeutics. In fact, several studies have already stressed the potency of siRNA-based strategies in knocking down the expression of specific targets in vivo for the treatment of different diseases [7-10], and many proposed therapies have completed phase I clinical trials, while others have already progressed into more advanced evaluation stages [11-13].

\subsection{Advantages of siRNA Therapeutics}

siRNA can be categorized into conventional, sticky and Dicer substrate siRNA. Conventional siRNA is synthetic dsRNA molecule bearing 19-25 base pairs and two dTdT overhangs at the 3 '-ends, which is designed to mimic the Dicer cleavage product and, therefore, directly enter RISC for triggering the RNAi mechanism [14]. Different from conventional, siRNA with short complementary An/Tn ( $n=5^{-}$ 8) overhangs, (instead of dTdT overhangs), named sticky siRNA, can be used, which considerably increases gene silencing efficiency. In addition to sticky siRNA, competent Dicer substrate siRNA (dsiRNA) of 25-30 nucleotides can be up to 100-fold more potent than conventional 21-mer duplex siRNA when targeted to the same sequence location. This dsiRNA bears an asymmetric blunt end and an over-hang at the 3 '-end that can be optimally processed by Dicer, hence yielding higher and more durable RNAi effect.

Among the different mechanisms to silence protein expression, siRNAs area very good choice as it is easy to dis-cover unmodified siRNAs that work with high potency. Compared to antisense oligonucleotides (ASOs), siRNAs have two strands, which simplifies their delivery and make siRNAs more resistant to nuclease degradation [15-17]. In addition, siRNAs show a more potent and prolonged therapeutic effect, thanks to the mentioned catalytic mechanism. Regarding dsRNAs, the antisense strand of siRNA is completely complementary to the mRNA target and has higher target recognition and binding compared to the other RNA molecules which are only partially complementary to the target mRNA $[18,19]$. Moreover, the total understanding of the methodology for siRNA synthesis enables preparation of a siRNA that selectively shuts off a targeted gene. In fact, specific siRNAs are now commercially available to silence almost any gene and in various different organisms. Important to notice that the down-regulation using siRNAs is transient. This may be adequate for some purposes where a temporary effect is needed. In situations requiring a persistent effect, repeated administrations are necessary.

INSTITUTO DE INVESTIGAÇÃO EINOVAÇA UNIVERSIDADE DO PORTO

Rua Alfredo Allen, 208 4200-135 Porto 
Due to the high power and lower off-target interaction of siRNA among all the antisense molecules, the use of siRNA has been considered the most promising tool being applied to personalized medicine $[20,21]$.

\section{3. siRNA: Barriers, Challenges and Delivery Vectors}

Despite the great advances achieved during the last years on the understanding and harnessing of the RNAi-mediated gene silencing mechanisms, some aspects are yet to be improved in order to translate RNAi-based therapeutics into the clinics [22-24]. For instance, few studies reported nonspecific effects triggered by siRNA-based therapeutics, as the mentioned off-target silencing (although low) and activation of the interferon system [25-29]. The recognition of this unintended gene modulation has led to the improved design of siRNA sequences by the use of appropriate algorithms, the establishment of several rules for siRNA design and the introduction of chemical modifications into the nucleic acid (NA) structure, which ultimately lead to minimal off-target activity [30].

Nevertheless, the main challenge is related to the siRNA transport and delivery. Due to its large molecular weight ( $\sim 14 \mathrm{kDa}$ in average) and polyanionic nature (negative phosphate groups), naked siRNA does not freely cross the cell membrane. Also, naked siRNA can be rapidly degraded by endonucleases when administrated and has a very short life in circulation. Therefore, it is now commonly accepted that the widespread use of siRNA therapeutics will require the use of clinically suitable, safe and effective delivery vehicles with the ability to protect naked siRNA, surpass the different extra- and intracellular barriers and efficiently deliver it into cells with minimal toxicity [3136]. The extra- and intracellular barriers and the corresponding challenges in the vector-mediated siRNA delivery include: a) protect siRNA against degradation by endonucleases present in the extraand intra-cellular milieu, b) avoid renal clearance, particularly relevant in the case of systemic administration, c) delivery to the desired site of action and avoid non-specific delivery, d) pro-mote cellular internalization, e) favor endosomal escape, f) siRNA release from the vector and access to the cytoplasmic and to the RNAi machinery to permit an effective gene silencing process, and g) avoid vector intra- and extracellular accumulation by ineffective clearance after accomplishing their biological function (i.e. release the siRNA cargo). Additionally, the delivery vector must avoid unspecific binding to serum proteins, preventing aggregation and recognition by the complement system.

Two classes of vehicles for siRNA are clearly distinguishable: viral and non-viral based vectors [37-39]. Even though viral based vectors have been extensively studied, showing high transfection efficiency rates, the adverse effects such as mutagenesis and immunogenicity are important obstacles still to overcome [40-43] which have limited their use in vivo. Furthermore, the low-scale production and storage difficulties [43] remain crucial limitations that raise concerns for its translation to the clinic. These facts have encouraged the development of non-viral cationic vehicles for siRNA delivery [39].

Electrostatic interactions between negatively charged siRNA and cationic polymers or macromolecules are the basis, in the great majority of cases, for the non-viral vector-mediated siRNA delivery. Most of the siRNA carriers tested so far have been mainly based on cationic systems previously developed for the delivery of plasmid DNA (pDNA) such as liposomes, lipids, cell penetrating peptides, natural and synthetic polymers and, more recently, dendrimers. However, fundamental differences between pDNA and siRNA molecules regarding size, morphology, flexibility and charge, can result in a less efficient interaction and lower protection of the latter [44]. Thus, the cationic vectors used for gene delivery do not necessarily result in optimal vectors for this small double-stranded NA [45-47]. Consequently, design and optimization of cationic vectors for the delivery of siRNA are required [47].

INSTITUTO DE INVESTIGAÇÃO EINOVAÇA UNIVERSIDADE DO PORTO

Rua Alfredo Allen, 208 4200-135 Porto 


\section{DENDRIMERS}

In 1978, Voëgtle et al. synthesized a new class of multiarmed molecules ("cascade molecules") [48]. The further increase in the complexity of these branched molecules by Denkewalter, Tomalia, Newkome, Frechet and colleagues led to larger structures/architectures, then coined as "dendrimers" [49-52]. Dendrimers comprise: a) a central core with at least two reactive groups, b) repeating units linked to the central core and distributed/arranged in concentric layers named "generations" (G), and c) high number of terminal functional groups on their surface (Fig. 2a). This "treelike" structure is depicted by the word dendrimer (from Greek: dendron = tree and meros = part), which relates to the distinctive organization of their branched blocks.

Soon, it was shown that dendrimers, in their cationic form, had something special to offer also as non-viral vectors in the gene therapy field, due to their capacity to complex and protect NAs in compact nanostructures (Fig. 2b) [53]. Moreover, their exclusive structural characteristics: globular, well-defined and highly branched structure, low polydispersity, tunable size and the possibility of controlled multifunctionalization (due to the presence of chemical handles on the dendritic periphery - multivalency), further allow a specific, fine and precise design of smart dendritic carriers for the NA delivery field.

Dendrimers are synthesized mainly by two different iterative synthetic approaches: divergent [48, $50,51]$ or convergent [52], which allow their accurate design. In the divergent route, introduced by Tomalia, Newkome, and Voëgtle, dendrimers grow layer-by-layer from the core towards the periphery. The core molecule reacts with monomeric molecules (repeating unit) containing one reactive and at least two inactive branched sites, yielding the first-generation dendrimer ( $\left.\mathrm{G}_{1}\right)$. Then, the surface of this $\mathrm{G}_{1}$ is activated for reaction with more repeating units. This process is repeated several times until the dendrimer of the desired generation and, therefore, size is formed. On the other hand, the convergent approach introduced by Fréchet et al. consists of the synthesis of branched individual dendrons, which are finally linked with a multifunctional core. The divergent methodology is susceptible to defective monomeric molecule assembly due to the higher number of reactions performed simultaneously, and thus, purification is usually required after each step [54]. Consequently, the probability of byproduct formation boosts with the generation, rendering lower over-all yields. Conversely, in the convergent synthesis only a limited number of groups are active per reaction, therefore, the probability of structural flaws is lower [54]. However, one disadvantage of the latter is its low ability to grow dendrimers until higher generations due to the steric hindrance between dendrons in the last step, although the selection of a suitable core (size and multivalency) can help to reduce these steric hindrances [54].

Finally, it is worth mentioning that new user-and environmentally-friendly synthetic approaches with higher reaction efficiency and step number reduction, such as "Lego" [55] and "click" [56] chemistry, and other accelerated and orthogonal synthesis strategies [57, 58], have been reported to overcome the drawbacks and the tedious purification intensive iterative processes of the previously mentioned classical strategies.

\section{DESIGNING DENDRIMERS FOR SIRNA DELIVERY}

Cationic dendrimers represent particularly attractive class of non-viral vehicles for siRNA, since they are able to complex and protect this NA in compact nanostructures, coined "dendriplexes" (dendrimer-NA complexes) (Fig. 2b), There-fore, they contribute to surpass the previously mentioned extra- and intracellular barriers, towards an efficient delivery of exogenous therapeutic siRNA into cells.

INSTITUTO DE INVESTIIGAÇÃO EM INOVAÇAO UNIVERSIDADE DO PORTO

Rua Alfredo Allen, 208 4200-135 Porto 
The development and optimization of highly efficient and rapid synthetic approaches together with the design of novel orthogonal building blocks have allowed the synthesis of an ample range of different dendritic compounds and families with monodisperse nanosizes and great number of functional end groups, what also allows attaching different ligands in a controllable manner, leading to optimized dendritic nanocarriers. Probably, the dendritic structures most extensively investigated for siRNA delivery have been the poly(amidoamine)(PAMAM) [59], poly(propylene imine) (PPI) [6o] and poly(L-lysine)-based (PLL) $[61,62]$ dendrimers (all commercially available), as well as carbosilane [63] and triazine [47] dendrimers. Even commercial gene transfection reagents such as PolyFect ${ }^{\circledR}$, SuperFect ${ }^{\circledR}$ and PrioFect ${ }^{\circledR}$ based on PAMAM dendrimers initially developed for DNA delivery, have also been shown to efficiently mediate siRNA delivery $[64,65]$.

The primary interaction between cationic dendrimers and siRNA is electrostatic. Consequently, dendriplex stability and NA delivery profile usually improve with the dendritic generation [53, 66-68]. Nevertheless, it has also been observed that higher generations do not always lead to higher transfection efficiencies [60,69]. This could be explained since dendrimers of lower generation may interact with NAs more efficiently than the higher generations as a result of their more flexible structure [70].

Despite the charge neutralization during the condensation process, when the molar ratio between the cationic groups from the dendrimer and the phosphate groups from the NA is above 1, the complexes preserve an excess of positive charge on their surfaces, which can result in cellular toxicity. Therefore, it is important to assess not only the toxicity of the free used cationic dendrimers, but also the one that may be elicited by the dendriplexes. The latter will be more important in the short-term, i.e. during transport, whereas free dendrimer toxicity may have a long-term effect, after NA delivery upon dendriplex disassembly.

Although the internal dendrimer structure plays a significant role in determining the biological performance of these structures [71], the characteristics of their surface groups will predominantly determine pharmacokinetics and biocompatibility $[72,73]$. In fact, cationic dendrimers will interact more strongly with the negatively charged surface of the cell membranes than anionic or neutral ones, and therefore they will be more cytotoxic $[72,74]$. It seems clear that higher generation dendrimers, besides less biocompatible, will be more toxic because of the higher number of positive charges. Therefore, it could be concluded that cationic dendrimers toxicity is concentration and generation dependent $[75,76]$. But contradictory data can be found in the literature regarding in vivo tests. Some studies show that PAMAM and PPI dendrimers, especially at low generations, are not as toxic as initially described [77-81]. However, others have reported toxicity profiles for the same dendrimers [82-84]. It should be noted that in vivo cytotoxicity will also depend on the dose and administration route [72]. Therefore, dendrimer characteristics (chemistry, size and charge - the last two ones closely related to generation) will also be important in the choice of the administration route and, consequently, on the in vivo biodistribution $[72,85-87]$. These issues will be further discussed in detail in the following sections.

Because of this controversial toxicity related to cationic dendrimers, much effort has been put into decrease /improve/optimize their cytotoxicity profile by surface engineering. For instance, acetylation of PAMAM dendrimers to reduce the number of primary amines [88] or also the use of hydroxyl-terminated PAMAM $G_{4}$ dendrimers with quaternized internal amines [89] are some of the investigated strategies to improve biocompatibility. However, in this regard, the most common approach for masking the dendrimers' charge and improving their solubility and biocompatibility, while increasing their circulation time in the blood stream, is to tether chains of poly(ethylene glycol) (PEG) to the dendritic backbone (PEGylation) [90] (Fig. 2). Moreover, other promising antibiofouling/non-fouling polymers have emerged as possible alternatives to PEG, such as zwitterionic polymers [91, 92], poly(2-oxazoline)s [91, 93, 94], poly peptoids [91], polycarbonates Version: Postprint (identical content as published paper) This is a self-archived document from i3S - Instituto de Investigação e Inovação em Saúde in the University of Porto Open Repository For Open Access to more of our publications, please visit http://repositorio-aberto.up.pt/

INSTITUTO DE INVESTIIGAÇÃO EINOVAÇAOO UNIVERSIDADE DO PORTO

Rua Alfredo Allen, 208 4200-135 Porto Portugal

+351220 408800

info@i3s.up.pt www.i3s.up.pt 
[95], among others. Although there are already a few reports in which some of these alternative polymers are attached to dendritic structures $[92,94]$, further studies are expected to test their favorable properties when linked to dendrimers.

Besides this, the possibility of precise chemical multi-decoration of dendrimers allows decreasing their unfavorable properties, such as the mentioned cytotoxicity, while improving the gene silencing effect, favoring the design of effective dendrimer-based siRNA nanocarriers. The main modification strategies of the dendrimers being explored to optimize their vectorization capability include:

1) The tethering to the dendrimer surface of different molecules, such as amino acids [47, 96-98], cyclodextrins [99-103] and hydrophobic moieties [47, 88, 104-107] in an optimized percentage and form. These modifications aim to increase the dendriplex stability and siRNA protection capability, as well as to enable the parent dendrimer to traverse the cell membrane, disrupt the endosomal mem-brane and/or facilitate endosomal escape - one critical challenge when talking about non-viral vector mediated siRNA delivery [108].

2) Adjustment of the core structure $[66,68,109-115]$ to enhance siRNA transfection efficiency. For instance, PAMAM dendrimers were studied with different types of core: a flexible core consisting on triethanolamine (TEA) [68, 113, 114], and a rigid poly(phenylene vinylene) (PPV) core [112]. Also, the focal point of dendrons can be used for linking moieties, mainly hydrophobic molecules, with the same aim of improving gene silencing $[116,117]$.Fig. (2). Schematic representation of: a) a dendrimer with attached chains of poly(ethylene glycol) (PEG) and a target molecule, b) siRNA/dendrimer complex (dendriplex).

3) Finally, the conjugation of several ligands and target molecules (Fig. 2), such as peptides and proteins, tailored to attain an efficient and site-specific (cells and tissues) siRNA delivery is also an attractive strategy $[62,103,118-123]$.

In addition to these dendrimer modifications, the suitable choice of the generation number (according to the dendritic family), will also have a significant impact on the enhancement of the transfection efficiency 47,68$]$.

Despite all these improvements on the design of dendrimers to act as vectors for siRNA delivery, the non-biodegradability under physiological conditions of the most commonly used dendritic structures in the NA delivery field remains a weak point that scientists need to further address $[54,72,124,125]$. After accomplishing their biological function - release the siRNA cargo - non-biodegradable dendrimers can also lead to cytotoxicity induced by the accumulation of non-degradable synthetic materials inside cells/tissues $[86,124]$. Therefore, the ideal delivery vehicle should be biodegradable to prevent bioaccumulation and subsequent cytotoxicity [86, 124-126]. Moreover, the dendrimers' biodegradability can also contribute to the efficient release of the transported NA [125, 127], and consequently yield higher RNAi.

In the following sections, some of the most significant and recent advances in the use of dendrimers as siRNA vectors in in vivo applications are revised. We cover the use of different dendrimers, distinct administration routes, toxicity issues, as well as the targeting of a specific tissue or disease, highlighting the caveats and potential of dendrimers as nanocarriers for therapeutic applications.

\section{IN VIVO APPLICATIONS}

The administration of siRNA dendriplexes to organisms requires preliminary extensive studies in the test tube and also with cells in culture. The strategies tested in vivo are, therefore, the result of innumerous iterative improvements previously tested in vitro. The delivery of siRNA mediated by

Version: Postprint (identical content as published paper) This is a self-archived document from i3S - Instituto de Investigação e Inovação em Saúde in the University of Porto Open Repository For Open Access to more of our publications, please visit http://repositorio-aberto.up.pt/

INSTITUTO DE INVESTIGAÇÃO EM SAUUDE UNIVERSIDADE DO PORTO

Rua Alfredo Allen, 208 4200-135 Porto 
dendrimers has been applied to date in different paradigms, with different aims and using different strategies. These studies in vivo using dendrimers to carry siRNA will be analyzed regarding its success rate, efficiency, toxicity and organ/cell specificity.

\subsection{Dendrimer Types Applied In Vivo}

Among the different dendrimers explored for siRNA delivery (PAMAM, PPI, PLL, carbosilane, and triazine), PAMAM has been the most widely used and studied vector in in vivo applications (Table 1). A large variety of modifications have been performed and tested in order to overcome the known obstacles faced in the complex in vivo environment.

In 2009, an approach using polyvalent dendrimer-bearing magnetic nanoparticles ("dendriworm"), which allow to locate in vivo the nanoparticles by imaging techniques, were used to carry siRNA to the most common and most aggressive brain cancer - a glioblastoma induced in mice [111], the most common and most aggressive brain cancer. For dendriworm development, cystamine core $\mathrm{G}_{4}$ PAMAM dendrimers were reduced yielding thiol dendrons. Then, amine-modified, cross-linked strings of spherical iron oxide nanoparticles coated with a biocompatible polymer (Dextran), named "nanoworms" [128], were prepared. Finally, reduced dendrons and nanoworms were conjugated using the heterobifuctional linker succinimidyl 3-(2-pyridyldithio) propionate (SPDP). The effects of siRNA delivered by den-driworms to the brain parenchyma were studied in healthy and brain tumor tissue, after intracranial infusion with an osmotic pump for a long period of time ( 3 and 7 days). These dendriworms showed improved proton sponge effect and enhanced endosomal escape efficiency when compared to dendrimers or nanoworms, resulting therefore in a better siRNA silencing.

Another group has reported promising results using a flexible TEA-core PAMAM dendrimer for delivering a cocktail of anti-HIV-1 Dicer substrate siRNAs in a humanized mouse model [113]. These dendriplexes suppressed viral infection by several orders of magnitude compared to free siRNA, which constitutes a big step in the treatment of HIV infection.

Liu and colleagues developed arginine-terminated dendrimers with the aim of combining the appropriate properties of the TEA-core PAMAM dendrimer in siRNA delivery and the cellpenetrating advantages of the arginine-rich motif, which enhances cell membrane penetration. This proved to be effective in delivering siRNAs, leading to potent gene silencing in vivo [129].

An efficient strategy, also using a TEA-core PAMAM dendrimer, to deliver heat shock transcription factor 27 (Hsp27) sticky siRNA to prostate cancer cells was explored by Peng's group. It produced potent gene silencing of Hsp27, which in turn lead to a notable anticancer effect [114]. The same team also reported a lipid/dendrimer hybrid bearing a hydrophobic long alkyl chain and a low generation hydrophilic PAMAM dendron was used in a prostate cancer mouse model [130]. This system displayed the advantageous delivery features of both lipid and polymer vectors. Hsp27 siRNA was delivered locally to the tumor and a high rate of success for gene silencing and anticancer activity was obtained.

As previously mentioned, other types of dendrimers appropriately modified for in vivo applications, have also been successfully employed with relevance (Table 1). Taratula et al. proposed a strategy using PPI dendrimers in which siRNA nanoparticles were caged with a dithiol containing cross-linker molecules and coated with PEG polymer [121]. These modifications provided lateral and steric stability to withstand the aggressive environment in the blood. Reduction of the intramolecular disulfide bond in the cytoplasm triggered the release of siRNA in cancer cells with success. The targeting delivery approach was obtained by conjugation to the dendriplexes of the luteinizing hormone-releasing hormone peptide, which directed the nanoparticles to the lung cancer cells. 
Serramia et al. reported the delivery of siRNA to the brain using a carbosilane dendrimer carrier [131]. After cell culture studies with these dendriplexes, their ability to cross the blood-brain barrier (BBB) was investigated and it was found that they efficiently reached the brain after a retro-orbital injection administration.

Very recently, 1,500 modular dendrimers based on 2-(acryloyloxy)ethyl methacrylate (AEMA), with chemically diversified cores, peripheries and generations modified with ester bonds, were synthesized by a sequential modular synthesis strategy [87]. From these, 50 top lead $G_{1}$ to $G_{4}$ dendrimers were tested in vivo for siRNA delivery. After selecting five dendrimers that led to knockdown with high potency, toxicity studies were performed and three dendrimers were excluded due to significant toxicity, which was shown by weight loss. The remaining two best dendrimers were tested in an aggressive liver cancer model, where the one with a lineal pentamine core and octane-1thiol surface modified, was the best tolerated and led to a significant high siRNA accumulation in the tumor.

\subsection{Route of Administration}

Therapeutics can be introduced into the body by various routes such as intravenous (i.v.), intraperitoneal (i.p.), intra-muscular, subcutaneous, among others. [132]. The route of administration has a profound effect on the accessibility of molecules/structures to their respective target site, as well as the speed and the efficiency with which the therapeutic will act. Consequently, it will have a profound impact on the in vivo performance of the administered system. When choosing the route of administration for the nanoparticle/dendriplex, one has to equate various aspects: a) the accessibility to the target site, b) the least invasive technique that still is effective in delivering therapeutic amounts of the selected agent, c) the volumes and frequency of administration, d) possible side effects, e) stability of the dendriplex after delivery, f) clearance through the body, and g) toxicity.

The most traditional route for the delivery of dendrimers and dendriplexes is the i.v. route [123 and Table 1]. With this systemic administration, it is common to find dendriplexes in the liver as well as in the spleen (though not so often studied). This accumulation is explained since these are organs of the reticuloendothelial system responsible for the clearance of foreign materials by macrophage uptake. It is also common to find dendriplexes in the kidneys. Renal excretion of dendrimers after systemic administration is known and therefore it is expected that dendrimers are present in this organ. For example, the fate of free cationic PAMAM dendrimers ( $G_{3}$ and $G_{4}$ ) and anionic PAMAM dendrimer ( $(\mathrm{G} 2.5,3.5$ and 5.5) after i.v. administration has been studied, to find that these materials accumulate in the liver and also that they are cleared from the blood via the kidney though with different clearance rates [146]. Moreover, it was also observed that after i.p. injection, most of the administrated dendrimers were transferred into the blood within an hour and exhibited a similar clearance pattern to the results found after i.v. injection. One of the main problems in systemic administration of cationic macromolecules is vector aggregation in the presence of serum that in the context of siRNA delivery mediated by dendrimers can result in nanoparticle disintegration, siRNA release and degradation. As mentioned before, PEGylation of the nanoparticle structures can prevent particle aggregation and increase their stability in serum. Therefore, this is a very common dendrimer and dendriplex modification for in vivo purposes. To overcome some of the limitations associated with systemic administration, local delivery of dendriplexes can be performed which increases site direct activity and minimizes systemic toxicity. This type of administration is found in various cancer studies (Table 1 ) where for example TEA-core PAMAM dendrimers complexed with siRNA have been directly administered to the tumor site [115]. Also regarding cancer, a useful strategy in brain is the use of convection enhanced delivery (CED) though it is very invasive due to the intracerebral injection [111]. A heart local injection has also been effective in improving cardiac function in a mice model of cardiovascular disease [137].

INSTITUTO
DE INVESTITGAÇÃO
EINOVAÇÃO
EM SAUUDE
UNIVERSIDADE
DO PORTO
Rua Alfredo Allen, 208
4200-135 Porto
Portugal
+351 220408800
info@i3s.up.pt
www.i3s.up.pt

DEINVESTIGA E INOVAÇÃO UNIVERSIDADE DO PORTO

www.i3s.up.pt 
The choice of the route of administration of the dendriplexes sometimes requires adjustments in its formulation. Such was the case in the study performed with radiolabeled [32P]-siRNA/PAMAM dendriplexes, where intranasal administration was chosen in order to reach the brain [135]. The dendriplexes were administered within an in situ forming mucoadhesive gel so as to increase the retention time of the dendriplexes in the nose mucosa and potentiate the rate of success after administration.

When repeated administrations are required due to the siRNA transient effect, more invasive routes of administration like the intracranial or intramyocardial are not a viable option.

Therefore, the choice for the route of administration has to take into account different factors, such as the purpose of the delivery, the dendrimer characteristics and the frequency of administration, which in turn will dictate the effectiveness of the procedure.

\subsection{Biodistribution}

As seen so far, dendrimers can be better suited for delivering siRNA to a specific organ, cell population or a diseased site depending on its composition, generation, size, surface functional groups and modifications. All of these characteristics will affect their biodistribution and, consequently, the RNAi efficiency. As an example, Anderson's group, employed a combinatorial approach, with PAMAM and PPI dendrimers modified with epoxide-terminated alkyl chains of increasing length to deliver siRNA to endothelial lung cells [107]. It was observed that the optimized formulations that included cholesterol, improved endothelial cell uptake of siRNA in vivo, consequently increasing tunica interna endothelial cell kinase (Tiez) lung knockdown. It was reasoned that when coupled with cholesterol, more serum proteins as for example albumin, were able to adsorb to the dendriplex, which in turn enhanced endothelial cell uptake. Moreover, the endothelium of other organs was also examined, but the knockdown effect was most potent in the lung because of thedendriplexes higher avidity for lung endothelial cells. These findings may have applications in the treatment of dysfunctional lung endothelium. Again, the same team synthetized a library of different dendrimers to deliver siRNA preferentially to: a) endothelial cells in the liver, or b) endothelial cells and hepatocytes, or c) endothelial cells, hepatocytes, and liver tumor cells in vivo[106]. The differential tropism of the dendriplexes to different cells within the liver was influenced by the carbon chain length of the alkyl epoxide and the ratio of cholesterol used in its formulation. Therefore, besides performing modifications to direct the dendriplexes to a specific organ, it is also possible to target the dendriplexes to distinct cell sub-populations within the same organ by tuning its formulation. Regarding cancer research, previous studies suggested that vascularized tumors experience increased uptake of nanoparticles due to the their leaky vasculature and consequent enhanced permeation and retention (EPR) effect [147]. This phenomenon is the rationale for the higher accumulation of dendriplexes after systemic administration in such tumors. To increase the amount of dendriplexes reaching the tumor (or in fact any target organ) after an i.v. administration, it is important to extend its circulating time in blood, which can be attained by, for example, PEGylation as previously mentioned [9o]. Also, the size is an important parameter to take into account. Addition of successive layers (generations) gradually increases molecular size and amplifies the number of surface groups present, which in principle will allow to increase proportionally the amount of bound siRNA. But the size will also impact on the dendrimer biodistribution, as was seen using a 3D multicellular tumor spheroid (MCTS) model where smaller PAMAM dendrimers not only diffused more rapidly in the extracellular matrix, but also efficiently penetrated to the MCTS core compared to their larger counterparts [148].

In the field of nanoparticle delivery to the central nervous system (CNS), there are additional major obstacles to the success of the procedure. The BBB prevents most small molecules and nearly all macromolecules from entering the CNS [149]. Current strategies used for dendriplex delivery to the Version: Postprint (identical content as published paper) This is a self-archived document from i3S - Instituto de Investigação e Inovação em Saúde in the University of Porto Open Repository For Open Access to more of our publications, please visit http://repositorio-aberto.up.pt/

INSTITUTO DE INVESTIGGAÇÃO EINOVAÇA UNIVERSIDADE DO PORTO

Rua Alfredo Allen, 208 4200-135 Porto Portugal

+351220 408800

info@i3s.up.pt www.i3s.up.pt 
brain include invasive and local delivery. Direct injection is mostly appropriate for local activity, as for example in brain tumors when there are no metastases, but it is not adequate when the pathological impact is widespread and the invasiveness nature of the technique surpasses its benefits. Therefore, systemic delivery is a possible option to reach the brain when the BBB is compromised such as in stroke. However, this method of delivery also leads to nanoparticles delivery to other organs besides the brain, which might result in unintended effects. To overcome this lack of specificity, tageting moieties can be added to the surface of the dendrimer as mentioned in previous sections. This should lead to a certain preferential localization. As an example, transferrin addition to a G3 PPI dendrimer increased significantly the dendrimer BBB crossing that in turn increased the amount in the brain [150]. Many reports also exist in cancer research where, for instance, folic acid is added to the dendrimer resulting in the targeting to the tumor [101].

To conclude, dendriplexes biodistribution depends not only on the administration site, but also on the dendrimer itself i.e. its size, composition and post-synthesis surface modifications (PEGylation, targeting molecules, etc.).

\subsection{In Vivo Toxicity}

Cell culture studies have shown that cationic dendrimer and dendriplex cytotoxicity is mainly attributed to the interaction of their surface positive charge with negatively charged biological membranes. The interaction of dendrimers with biological membranes can result in membrane disruption via "nanohole" formation, membrane thinning and erosion, which lead to necrosis/nonapoptotic cell death [151]. Several reports have carefully described the influence of dendrimer chemistry, size and charge on biological membranes integrity [146]. Moreover, recent works propose that, besides membrane destabilization, toxicity may also come up from impaired oxidative metabolism resulting from mitochondrial dysfunction [152] and changes in endogenous gene expression [153] that ultimately lead to apoptotic cell death.

To minimize the possible toxicity, different strategies in the synthesis and modification of the cationic dendrimers have been performed, as described above. However, to date there is no "standard" strategy in the dendrimers synthesis/modification in order to overcome a possible toxicity after in vivo administration. Some authors claim that the use of lower generation dendrimers may also diminish the likelihood of immune system activation and inflammatory response associated with the use of higher generation dendrimers [151]. But there is no consensus on this subject. For instance, Okuda and colleagues concluded that G6-PAMAM dendrimers did not induce any measurable hepatic damages [154], while a lower generation G4-PAMAM dendrimer even induced antiinflammatory activity [78]. Regarding surface chemical engineering, toxicity profiles are not always improved by functionalization. As an example, Albertazzi and co-workers explored the effect of unmodified and $\mathrm{C}_{12}$-acetylated G4-PAMAM dendrimers in the CNS and they found in vivo toxicity only for the modified dendrimer [155]. However, this could be surpassed if modifications are tuned regarding aliphatic chain length and percentage of functionalization. Conflicting data can arise because each dendrimer will have its own requirements for synthesis and/or modification in order to overcome toxicity and, as commented in the previous sections, the needed modifications have to be carried out in an optimized form. Also, each intended purpose or function attributed to the dendrimer will dictate its structure, the concentration or amount needed and, concomitantly, this will affect toxicity. Thus, each dendrimer has to be evaluated in the proper context and taking into consideration the efficiency in which it reaches a certain tissue. So, in one situation the dendrimer may not be toxic while in another it can constitute a problem if for instance it accumulates in increased amounts.

Regarding dendriplexes, it is obvious that their toxicity depends on the toxicity of the parent dendrimer. However, after complexation with the NA, the toxicity, for both systems (parent

INSTITUTO
DE INVESTIIGAÇÃO
EINOVAÇÃO
EM SAUUDE
UNIVERSIDADE
DO PORTO
Rua Alfredo Allen, 208
$4200-135$ Porto
Portugal
+351 220408800
info@i3s.up.pt
www.i3s.up.pt

DEINVEST E INOVAÇÃO UNIVERSIDADE DO PORTO

Rua Alfredo Allen, 208 Portugal

info@i3s.up.pt www.i3s.up.pt 
dendrimer and dendriplex) should be equally assessed. Nevertheless, most of the reports show similar profiles, as recently reported by Chen et al., who used self-assembled small amphiphilic dendrons into nanosized supramolecular dendrimer micelles resembling high generation dendrimers [156]. These supramolecular structures showed no toxicity either alone or when complexed with the siRNA, and the purpose of effective gene silencing was achieved.It is intuitive to accept that the dose and frequency of administration are also parameters to take into account when considering toxicity after dendriplex administration [151]. A too high dose or multiple administrations with short intervals can induce, for example, a lysosomal storage problem if the dendrimers do not degrade and accumulate in this organelle [157]. A balance should then exist between the lowest amounts of administered dendriplexes with the highest possible effect elicited by them.

The best practices in this area of research indicate that toxicity in in vitro cell culture should be assessed before in vivo toxicity studies are performed, in order to prove the safety of any nanoparticle. But, even though numerous in vitro studies have shown severe undesirable effects, recent reports indicate that these cannot be always extrapolated to in vivo settings [158]. So, dendrimer and dendriplex toxicity evaluation in vivo is essential and can be performed in many ways, as for example monitoring weight loss, organ histopathology, hemolysis (red blood cell morphology), alterations in transaminases, alterations in urea nitrogen levels, behavioral studies, lactate dehydrogenase activity in serum, interferon response or inflammatory response.

Watanabe and colleagues showed that delivery of apolipoprotein B (ApoB) - specific siRNA with G6 PLL dendrimers led to knockdown of ApoB in healthy mice liver without hepatotoxicity [143]. The potential toxicity was assessed by measuring the serum levels of aspartate aminotransferase (AST) and alanine aminotransferase (ALT), which are two enzymes located in liver cells that leak into the circulation when liver cells are injured.

Another study intended to deliver siRNA to the lung, showed that, at high doses, the $\mathrm{G}_{1}$ dendrimer-lipid derivatives of PAMAM and PPI dendrimers used did not cause chronic increases in pro-inflammatory cytokines and animals did not suffer weight loss due to toxicity [107].

Different kinds of carbosilane-based dendriplexes have shown good toxicity profiles in peripheral blood mononuclear cells and erythrocytes over extended periods of time [159].

Fortunately, in general, surface and/or core modified cationic dendrimers as well as their siRNA/dendriplexes display a good toxicity profile, do not show major histopathological changes nor exacerbate the inflammatory response (Table 1), which is significant for further translational studies.

\subsection{Therapeutic and Biomedical Applications}

siRNAs can be therapeutically applied as antiviral or anticancer agents, in CNS therapeutics, in inflammation or cardiovascular therapeutics, among others [160]. Dendritic structures make excellent delivery systems for siRNA delivery and their ability to target specific cells and to release the NA in a controlled manner without toxicity was already proven, as highlighted in this review. Reports in different areas have emerged as for example in cancer, HIV-1 infection, neurodegenerative diseases such as Familial Amyloidotic Polyneuropathy (FAP) and in stroke.

For cancer applications, siRNA delivery with dendrimers has been extensively studied in animal cancer models (Table 1). Some studies apply the dendriplexes directly to tumors [114, 115, 129, 130], others have performed systemic ad-ministration of dendriplexes functionalized with targeting moieties directed to cancer cells $[101,121]$, and also both approaches - intratumoral administration with cancer targeting moieties - have also been reported by Wei et al. [161]. In this last study, by using gold nanostar-based platform modified with PAMAM dendrimers, the authors proposed an

INSTITUTO
DE INVESTIIGAÇÃO
EINOVAÇÃO
EM SAUUDE
UNIVERSIDADE
DO PORTO
Rua Alfredo Allen, 208
$4200-135$ Porto
Portugal
+351 220408800
info@i3s.up.pt
www.i3s.up.pt


interesting diagnosis application for tumor computed tomography imaging. Additionally, a therapeutic approach combining both photothermal and gene therapy was also proposed in vivo. Other promising dual-delivery studies using siRNA and an anticancer drug, both complexed with the dendrimer can also be found in the literature, which significantly potentiated the antitumor effect of the drug $[115,140,142]$. This can occur by sensitizing the cancer cells to the chemotherapy due to coapplication of specific siRNAs responsible for regulating chemoresistance [162].

The previously mentioned study by Zhou and colleagues [113], in HIV-1 infected humanized mice, which suppressed infection after dendriplexes delivery, represents a promising strategy for the treatment of HIV.

In FAP, a hereditary disease caused by the liver expression of mutated transthyretin (TTR), Hayashi et al. used a lactosylated dendrimer $\left(\mathrm{G}_{3}\right)$ conjugated with $\alpha$-cyclodextrin as a novel hepatocytespecific siRNA carrier for TTR $[102,145]$. The dendriplex had a potent in vivo gene silencing effect in the liver without toxicity, constituting therefore an-other therapeutic tool for FAP treatment.

In brain ischemia studies, Kim and colleagues used arginine-modified PAMAM dendrimers $\left(\mathrm{G}_{4}\right)$ to deliver siRNA against High-mobility group box 1 (HMGB1) to the post-ischemic brain with success [133]. siRNA was detected $1 \mathrm{~h}$ after delivery and maintained for at least $12 \mathrm{~h}$ and, most significantly, neuroprotection was observed.

Based on the above, the siRNA/dendrimers-based nanomedicine shows very good prospects in biomedical application of various natures, and further studies accomplished in vivo, for future translation constitutes a worth-while goal.

\section{CONCLUSION}

Among the approaches explored in gene therapy, the down-regulation of protein expression mediated by siRNAs is one of the most promising strategies. However, its success will be intimately related with the development of efficient vectors. Although there have been many advances in this field, the design of an effective and non-toxic vehicle that allows the delivery of siRNA in the desired tissue or organ needs further improvements so as to widespread the therapeutic application of RNAi. In this context, dendrimers arose as promising candidates due to their globular, well defined, very branched and multifunctionalizable structure, their low polydispersity, as well as their particular capacity to complex and protect siRNA in compact nanostructures.

Many efforts have been made to develop and optimize dendritic structures for siRNA delivery. The possibility of multifunctionalization has allowed a great variety of chemical decorations/modifications, especially the ones introduced onto the dendrimer periphery, with the aim of decreasing cytotoxicity, while improving biocompatibility. Moreover, target molecules can be linked in a controllable manner in order to get tissue-or cell specificity. Regardless of the cost and regulatory obstacles associated, the targeted approach continues being of great interest for scientists, especially for in vivo applications, since it minimizes the complicated side effects besides maximizing the site-specificity.

However, despite this great advance in the design of dendrimers to act as effective vectors of siRNA, there are some aspects/issues that still need to be improved and/or sur-passed. For instance, as previously mentioned, one important drawback is the bioaccumulation of the vector and possible subsequent toxicity after accomplishing their biological function. Because of this, more fundamental research should be directed to develop fully biodegradable dendrimers, whose goal not only concerns toxicity, but also puts forward the design of "smart" controlled delivery systems. This aims at

INSTITUTO DE INVESTIIGAÇÃO EM INOVAÇAO UNIVERSIDADE DO PORTO

Rua Alfredo Allen, 208 4200-135 Porto 
triggering and/or sustaining the release of the therapeutic siRNA via the control of the vector degradation profile, as is being currently explored by us and others.

Besides optimizing the design of dendrimers for in vivo applications [163], it is important to consider also the pharmacokinetics so that a slower clearance and higher activity of the selected siRNA in the target site have to be observed. This is intimately connected to the amount and frequency of the doses that should be optimized and adjusted. Ultimately, it is obligatory to explore various safety issues in the pre-clinical scenario such as the degradability and biocompatibility. The benefits should always surpass the risks.

In the future, further contributions of dendriplex mediated siRNA delivery are expected, which may constitute a remarkable pre-clinical landmark in nanomedicine therapeutics. Combining all the aforementioned characteristics in one dendritic system would be a big step forward to translate therapeutic siRNA-dendriplexes into a clinical reality.

\section{CONSENT FOR PUBLICATION}

Not applicable.

\section{CONFLICT OF INTEREST}

The authors confirm that this article content has no con-flict of interest.

\section{ACKNOWLEDGEMENTS}

The authors acknowledge the financial support of the Fundo para a Investigação em Saúde (INFARMED, project reference FIS-2015-01_CCV_20150630-88), as well as the FEDER funds through the Programa Operacional Competitividade e Internacionalização- COMPETE 2020 and the Portuguese funds through FCT -Fundação para a Ciência e a Tecnologia in the frame of the project POCI-01-0145-FEDER-016639 (reference PTDC/CTM-NAN/3547/2014). V. Leiro is supported by the project NORTE-01-0145-FEDER-000012, financed by Norte Portugal Regional Operational Programme (NORTE 2020), under the PORTUGAL 2020 Partnership Agreement, through the European Regional Development Fund (ERDF). S.D. Santos is supported by FCT (SFRH/BPD/109297/2015). We thank João Pedro Garcia for his contribution to the dendriplex picture.

\section{REFERENCES}

[1] Fire A, Xu S, Montgomery MK, Kostas SA, Driver SE, Mello CC. Potent and specific genetic interference by double-stranded RNA in Caenorhabditis elegans. Nature. 1998;391(6669):806-11.

[2] Wianny F, Zernicka-Goetz M. Specific interference with gene function by double-stranded RNA in early mouse development. Nat Cell Biol. 2000;2(2):70-5.

[3] Bernstein E, Caudy AA, Hammond SM, Hannon GJ. Role for a bidentate ribonuclease in the initiation step of RNA interference. Nature. 2001;409(6818):363-6.

[4] Zamore PD, Tuschl T, Sharp PA, Bartel DP. RNAi: doublestranded RNA directs the ATPdependent cleavage of mRNA at 21 to 23 nucleotide intervals. Cell. 2000;101(1):25-33.

INSTITUTO DE INVESTIIGAÇÃO EINOVAÇA UNIVERSIDADE DO PORTO

Rua Alfredo Allen, 208 4200-135 Porto 
[5] Martinez J, Patkaniowska A, Urlaub H, Luhrmann R, Tuschl T. Single-stranded antisense siRNAs guide target RNA cleavage in RNAi. Cell. 2002;110(5):563-74.

[6] Hutvagner G, Zamore PD. A microRNA in a multiple-turnover RNAi enzyme complex. Science. 2002;297(5589):2056-60.

[7] Morrissey DV, Lockridge JA, Shaw L, Blanchard K, Jensen K, Breen W, et al. Potent and persistent in vivo anti-HBV activity of chemically modified siRNAs. Nat Biotechnol. 2005;23(8):1002-7.

[8] Niu XY, Peng ZL, Duan WQ, Wang H, Wang P. Inhibition of HPV 16 E6 oncogene expression by RNA interference in vitro and in vivo. Int J Gynecol Cancer. 2006;16(2):743-51.

[9] Halder J, Kamat AA, Landen CN, Han LY, Lutgendorf SK, Lin YG, et al. Focal adhesion kinase targeting using in vivo short interfering RNA delivery in neutral liposomes for ovarian carcinoma therapy. Clinical Cancer Research. 2006;12(16):4916-24.

[10] Frank-Kamenetsky M, Grefhorst A, Anderson NN, Racie TS, Bramlage B, Akinc A, et al. Therapeutic RNAi targeting PCSKg acutely lowers plasma cholesterol in rodents and LDL cholesterol in nonhuman primates. Proc Natl Acad Sci USA. 2008; 105(33): 11915-20.

[11] Tabernero J, Shapiro GI, LoRusso PM, Cervantes A, Schwartz GK, Weiss GJ, et al. First-in-humans trial of an RNA interference therapeutic targeting VEGF and KSP in cancer patients with liver involvement. Cancer Discov. 2013;3(4):406-17.

[12] Zuckerman JE, Davis ME. Clinical experiences with systemically administered siRNA-based therapeutics in cancer. Nature reviews Drug discovery. 2015;14(12):843-56.

[13] clinicaltrials.gov. [Accessed on February 2017]; Available from: https://clinicaltrials.gov/ct2/results?term=siRNA\&Search=Search

[14] Liu X, Peng L. Dendrimer Nanovectors for SiRNA Delivery. Methods Mol Biol. 2016;1364:127-42.

[15] Bertrand JR, Pottier M, Vekris A, Opolon P, Maksimenko A, Malvy C. Comparison of antisense oligonucleotides and siRNAs in cell culture and in vivo. Biochem Bioph Res Co. 2002;296(4):1000- 4.

[16] Turner JJ, Jones SW, Moschos SA, Lindsay MA, Gait MJ. MALDI-TOF mass spectral analysis of siRNA degradation in serum confirms an RNAse A-like activity. Molecular bioSystems. 2007;3(1):4350.

[17] Watts JK, Corey DR. Silencing disease genes in the laboratory and the clinic. J Pathol. 2012;226(2):365-79.

[18] Elbashir SM, Harborth J, Lendeckel W, Yalcin A, Weber K, Tuschl T. Duplexes of 21-nucleotide RNAs mediate RNA interference in cultured mammalian cells. Nature. 2001;411(6836):494-8.

[19] Aagaard L, Rossi JJ. RNAi therapeutics: principles, prospects and challenges. Adv Drug Deliv Rev. 2007;59(2-3):75-86.

[20] Potti A, Schilsky RL, Nevins JR. Refocusing the War on Cancer: The Critical Role of Personalized Treatment. Sci Transl Med. 2010;2(28). 
[21] Rao DD, Wang ZH, Senzer N, Nemunaitis J. RNA Interference and Personalized Cancer Therapy. Discov Med. 2013;81:101-10.

[22] de Fougerolles A, Vornlocher H-PP, Maraganore J, Lieberman J. Interfering with disease: a progress report on siRNA-based therapeutics. Nature Reviews Drug discovery. 2007;6(6):443-53.

[23] Castanotto D, Rossi JJ. The promises and pitfalls of RNAinterference- based therapeutics. Nature. 2009;457(7228):426-33 .

[24] Broderick JA, Zamore PD. MicroRNA therapeutics. Gene Ther. 2011;18(12):1104-10.

[25] Sledz CA, Holko M, de Veer MJ, Silverman RH, Williams BRG. Activation of the interferon system by short-interfering RNAs. Nat Cell Biol. 2003;5(9):834-9.

[26] de Veer MJ, Sledz CA, Williams BR. Detection of foreign RNA: implications for RNAi. Immunol Cell Biol. 2005;83(3):224-8.

[27] Hornung V, Guenthner-Biller M, Bourquin C, Ablasser A, Schlee M, Uematsu S, et al. Sequencespecific potent induction of IFNalpha by short interfering RNA in plasmacytoid dendritic cells through TLR7. Nature medicine. 2005;11(3):263-70.

[28] Judge AD, Sood V, Shaw JR, Fang D, McClintock K, MacLachlan I. Sequence-dependent stimulation of the mammalian innate immune response by synthetic siRNA. Nat Biotechnol. 2005; 23(4): 457-62.

[29] Jackson AL, Burchard J, Schelter J, Chau BN, Cleary M, Lim L, et al. Widespread siRNA "offtarget" transcript silencing mediated by seed region sequence complementarity. RNA. 2006; 12(7): $1179-87$.

[30] Petri S, Meister G. siRNA design principles and off-target effects. Methods Mol Biol. 2013;986:59-71.

[31] Nishikawa M, Huang L. Nonviral vectors in the new millennium: delivery barriers in gene transfer. Hum Gene Ther. 2001;12(8):861- 70.

[32] Kim DH, Rossi JJ. Strategies for silencing human disease using RNA interference. Nat Rev Genet. 2007;8(3):173-84.

[33] Mintzer MA, Simanek EE. Nonviral vectors for gene delivery. Chemical Reviews. 2009;109(2):259-302.

[34] Whitehead KA, Langer R, Anderson DG. Knocking down barriers: advances in siRNA delivery. Nature Reviews Drug Discovery. 2009;8(2):129-38.

[35] Jones $\mathrm{CH}$, Chen C-K, Ravikrishnan A, Rane S, Pfeifer BA. Overcoming nonviral gene delivery barriers: perspective and future. Molecular Pharmaceutics. 2013;10(11):4082-98.

[36] Gomes CP, Lopes CDF, Moreno PMD, Varela-Moreira A, Alonso MJ, Pêgo AP. Translating chitosan to clinical delivery of nucleic acid-based drugs. MRS Bulletin. 2014;39(01):60-70.

[37] Brummelkamp TR, Bernards R, Agami R. A system for stable expression of short interfering RNAs in mammalian cells. Science. 2002;296(5567):550-3.

INSTITUTO DE INVESTİGAÇÃO EINOVACÃO EM SAÚDE UNIVERSIDADE DO PORTO

Rua Alfredo Allen, 208 4200-135 Porto 
[39] Kesharwani P, Gajbhiye V, Jain NK. A review of nanocarriers for the delivery of small interfering RNA. Biomaterials. 2012; 33(29): 7138-50.

[40] Bessis N, GarciaCozar FJ, Boissier MC. Immune responses to gene therapy vectors: influence on vector function and effector mechanisms. Gene Ther. 2004;11:S10-S7.

[41] Baum C, Kustikova O, Modlich U, Li ZX, Fehse B. Mutagenesis and oncogenesis by chromosomal insertion of gene transfer vectors. Hum Gene Ther. 2006;17(3):253-63.

[42] Waehler R, Russell SJ, Curiel DT. Engineering targeted viral vectors for gene therapy. Nat Rev Genet. 2007;8(8):573-87.

[43] Bouard D, Alazard-Dany N, Cosset FL. Viral vectors: from virology to transgene expression. Brit J Pharmacol. 2009; 157(2): 153-65.

[44] Gary DJ, Puri N, Won YY. Polymer-based siRNA delivery: Perspectives on the fundamental and phenomenological distinctions from polymer-based DNA delivery. Journal of Controlled Release. 2007;121(1-2):64-73.

[45] Mintzer MA, Merkel OM, Kissel T, Simanek EE. Polycationic triazine-based dendrimers: effect of peripheral groups on transfection efficiency. New J Chem. 2009;33:1918-25.

[46] Merkel OM, Mintzer MA, Sitterberg J, Bakowsky U, Simanek EE, Kissel T. Triazine dendrimers as nonviral gene delivery systems: effects of molecular structure on biological activity. Bioconjug Chem. 2009;20(9):1799-806.

[47] Merkel OM, Mintzer MA, Librizzi D, Samsonova O, Dicke T, Sproat B, et al. Triazine dendrimers as nonviral vectors for in vitro and in vivo RNAi: the effects of peripheral groups and core structure on biological activity. Mol Pharm. 2010;7(4):969-83.

[48] Buhleier E, Wehner W, Vogtle F. "Cascade"- and "non-skid-chainlike" syntheses of molecular cavity topologies. Synthesis. 1978; 2: 155-8.

[49] Denkewalter RG, Kolc J, Lukasavage WJ, inventors; Google Patents, assignee. Surface modifying agents, metal chelating agents, substrates for drugs patent U.S. Patent 4289872. 1981.

[50] Tomalia DA, Baker H, Dewald J, Hall M, Kallos G, Martin S, et al. A new class of polymers: starburst-dendritic macromolecules. Polymer Journal. 1985;17(1):117-32.

[51] Newkome GR, Yao ZQ, Baker GR, Gupta VK. Micelles. Part 1. Cascade molecules: a new approach to micelles. A [27]-arborol. J Org Chem. 1985;50:2003-4.

[52] Hawker CJ, Frechet JMJ. Preparation of polymers with controlled molecular architecture. A new convergent approach to dendritic macromolecules. J Am Chem Soc. 1990;112(21):7638-47.

[53] Dufes C, Uchegbu I, Schatzlein A. Dendrimers in gene delivery. Adv Drug Deliver Rev. 2005; $57(15): 2177-202$.

[54] Mintzer MA, Grinstaff MW. Biomedical applications of dendrimers: a tutorial. Chemical Society Reviews. 2010;40(1):173-90.

INSTITUTO DE INVESTİGAÇÃO EINOVAÇÃO UNIVERSIDADE UNIVERSIDAD

Rua Alfredo Allen, 208 4200-135 Porto 
[55] Maraval V, Pyzowski J, Caminade AM, Majoral JP. "Lego" chemistry for the straightforward synthesis of dendrimers. J Org Chem. 2003;68(15):6043-6.

[56] Arseneault M, Wafer C, Morin JF. Recent Advances in Click Chemistry Applied to Dendrimer Synthesis. Molecules. 2015; 20(5):9263-94.

[57] Brauge L, Magro G, Caminade AM, Majoral JP. First divergent strategy using two $A B(2)$ unprotected monomers for the rapid synthesis of dendrimers. J Am Chem Soc. 2001;123(27):6698-9.

[58] Walter MV, Malkoch M. Simplifying the synthesis of dendrimers: Accelerated approaches. Chemical Society Reviews. 2012; 41(13): 4593-609.

[59] Kesharwani P, Banerjee S, Gupta U, Amin MCIM, Padhye S, Sarkar FH, et al. PAMAM dendrimers as promising nanocarriers for RNAi therapeutics. Mater Today. 2015;18(10):565-72.

[6o] Taratula O, Savla R, He HX, Minko T. Poly(propyleneimine) dendrimers as potential siRNA delivery nanocarrier: from structure to function. Int J Nanotechnol. 2011;8(1-2):36-52.

[61] Inove Y, Kurihara R, Tsuchida A, Hasegawa M, Nagashima T, Mori T, et al. Efficient delivery of siRNA using dendritic poly(Llysine) for loss-of-function analysis. Journal of Controlled Release. 2008;126(1):59-66.

[62] Watanabe K, Harada-Shiba M, Suzuki A, Gokuden R, Kurihara R, Sugao Y, et al. In vivo siRNA delivery with dendritic poly(Llysine) for the treatment of hypercholesterolemia. Molecular bioSystems. 2009;5(11):1306-10.

[63] Jimenez JL, Gomez R, Briz V, Madrid R, Bryszewsk M, de la Mata FJ, et al. Carbosilane dendrimers as carriers of siRNA. J Drug Deliv Sci Tec. 2012;22(1):75-82.

[64] Tsubouchi A, Sakakura J, Yagi R, Mazaki Y, Schaefer E, Yano H, et al. Localized suppression of RhoA activity by Tyr31/118- phosphorylated paxillin in cell adhesion and migration. J Cell Biol. 2002;159(4):673-83.

[65] Huang YZ, Zang MW, Xiong WC, Luo ZJ, Mei L. Erbin suppresses the MAP kinase pathway. J Biol Chem. 2003;278(2):1108- 14 .

[66] Zhou JH, Wu JY, Hafdi N, Behr JP, Erbacher P, Peng L. PAMAM dendrimers for efficient siRNA delivery and potent gene silencing. Chem Commun. 2006(22):2362-4.

[67] Perez AP, Romero EL, Morilla MJ. Ethylendiamine core PAMAM dendrimers/siRNA complexes as in vitro silencing agents. International Journal of Pharmaceutics. 2009;380(1-2):189-200.

[68] Liu XX, Liu C, Catapano CV, Peng L, Zhou JH, Rocchi P. Structurally flexible triethanolamine-core poly(amidoamine) dendrimers as effective nanovectors to deliver RNAi-based therapeutics. Biotechnology advances. 2014;32(4):844-52.

[69] Zinselmeyer BH, Mackay SP, Schatzlein AG, Uchegbu IF. The lower-generation polypropylenimine dendrimers are effective genetransfer agents. Pharm Res. 2002;19(7):960-7.

[70] Ottaviani MF, Furini F, Casini A, Turro NJ, Jockusch S, Tomalia DA, et al. Formation of supramolecular structures between DNA and starburst dendrimers studied by EPR, CD, UV, and melting profiles. Macromolecules. 2000;33(21):7842-51.

INSTITUTO DE INVESTİGAÇÃO EINOVAÇÃO UNIVERSIDADE UNIVERSIDAD

Rua Alfredo Allen, 208 4200-135 Porto 
[71] Caminade AM, Fruchon S, Turrin CO, Poupot M, Ouali A, Maraval A, et al. The key role of the scaffold on the efficiency of dendrimer nanodrugs. Nat Commun. 2015;6.

[72] Duncan R, Izzo L. Dendrimer biocompatibility and toxicity. Adv Drug Deliver Rev. 2005; $57(15): 2215-37$.

[73] Kaminskas LM, Boyd BJ, Porter CJ. Dendrimer pharmacokinetics: the effect of size, structure and surface characteristics on ADME properties. Nanomedicine (Lond). 2011;6(6):1063-84.

[74] Ottaviani MF, Favuzza P, Sacchi B, Turro NJ, Jockusch S, Tomalia DA. Interactions between starburst dendrimers and mixed DMPC/DMPA-Na vesicles studied by the spin label and the spin probe techniques, supported by transmission electron microscopy. Langmuir. 2002;18(6):2347-57.

[75] Gebhart CL, Kabanov AV. Evaluation of polyplexes as gene transfer agents. Journal of Controlled Release. 2001;73(2-3):401-16.

[76] Omidi Y, Hollins AJ, Drayton RM, Akhtar S. Polypropylenimine dendrimer-induced gene expression changes: the effect of complexation with DNA, dendrimer generation and cell type. Journal of Drug Targeting. 2005;13(7):431-43.

[77] Okuda T, Kawakami S, Maeie T, Niidome T, Yamashita F, Hashida M. Biodistribution characteristics of amino acid dendrimers and their PEGylated derivatives after intravenous administration. Journal of Controlled Release. 2006;114(1):69-77.

[78] Chauhan AS, Diwan PV, Jain NK, Tomalia DA. Unexpected in vivo anti-inflammatory activity observed for simple, surface functionalized poly(amidoamine) dendrimers. Biomacromolecules. 2009;10(5):1195-202.

[79] Chauhan AS, Jain NK, Diwan PV. Pre-clinical and behavioural toxicity profile of PAMAM dendrimers in mice. Proceedings of the Royal Society A: Mathematical, Physical and Engineering Sciences. 2010;466(2117):1535-50.

[8o] Ziemba B, Janaszewska A, Ciepluch K, Krotewicz M, Fogel WA, Appelhans D, et al. In vivo toxicity of poly(propyleneimine) dendrimers. Journal of Biomedical Materials Research, Part A. 2011;99(2):261-8.

[81] Albertazzi L, Gherardini L, Brondi M, Sato SS, Bifone A, Pizzorusso T, et al. In vivo distribution and toxicity of PAMAM dendrimers in the central nervous system depend on their surface chemistry. Molecular Pharmaceutics. 2013;10(1):249-60.

[82] Labieniec M, Ulicna O, Vancova O, Glowacki R, Sebekova K, Bald E, et al. PAMAM G4 dendrimers lower high glucose but do not improve reduced survival in diabetic rats. International Journal of Pharmaceutics. 2008;364(1):142-9.

[83] Li C, Liu H, Sun Y, Wang H, Guo F, Rao S, et al. PAMAM nanoparticles promote acute lung injury by inducing autophagic cell death through the Akt-TSC2-mTOR signaling pathway. Journal of Molecular Cell Biology. 2009;1(1):37-45.

[84] Jones CF, Campbell RA, Brooks AE, Assemi S, Tadjiki S, Thiagarajan G, et al. Cationic PAMAM dendrimers aggressively initiate blood clot formation. ACS Nano. 2012;6(11):9900-10.

INSTITUTO DE INVESTİGAÇÃO EINOVAÇA UNIVERSIDADE UNIVERSIDAD

Rua Alfredo Allen, 208 4200-135 Porto 
[85] Roberts JC, Bhalgat MK, Zera RT. Preliminary biological evaluation of polyamidoamine (PAMAM) Starburst dendrimers. Journal of biomedical materials research. 1996;30(1):53-65.

[86] Malik N, Wiwattanapatapee R, Klopsch R, Lorenz K, Frey H, Weener JW, et al. Dendrimers: relationship between structure and biocompatibility in vitro, and preliminary studies on the biodistribution of 125 l-labelled polyamidoamine dendrimers in vivo. Journal of Controlled Release. 2000;65(1-2):133-48.

[87] Zhou K, Nguyen LH, Miller JB, Yan Y, Kos P, Xiong H, et al. Modular degradable dendrimers enable small RNAs to extend survival in an aggressive liver cancer model. Proc Natl Acad Sci USA. 2016;113(3):520-5.

[88] Waite CL, Sparks SM, Uhrich KE, Roth CM. Acetylation of PAMAM dendrimers for cellular delivery of siRNA. Bmc Biotechnol. 2009;9.

[89] Patil ML, Zhang M, Taratula O, Garbuzenko OB, He HX, Minko T. Internally Cationic Polyamidoamine PAMAM-OH Dendrimers for siRNA Delivery: Effect of the Degree of Quaternization and Cancer Targeting. Biomacromolecules. 2009;10(2):258-66.

[9o] Thakur S, Kesharwani P, Tekade RK, Jain NK. Impact of pegylation on biopharmaceutical properties of dendrimers. Polymer. 2015;59:67-92 .

[91] Lowe S, O'Brien-Simpson NM, Connal LA. Antibiofouling polymer interfaces: poly(ethylene glycol) and other promising candidates. Polymer Chemistry. 2015;6(2):198-212.

[92] Liu KC, Yeo Y. Zwitterionic Chitosan-Polyamidoamine Dendrimer Complex Nanoparticles as a pH-Sensitive Drug Carrier. Molecular Pharmaceutics. 2013;10(5):1695-704.

[93] Luxenhofer R, Han YC, Schulz A, Tong J, He ZJ, Kabanov AV, et al. Poly(2-oxazoline)s as Polymer Therapeutics. Macromol Rapid Comm. 2012;33(19):1613-31.

[94] Kempe K, Onbulak S, Schubert US, Sanyal A, Hoogenboom R. pH degradable dendronfunctionalized poly(2-ethyl-2-oxazoline) prepared by a cascade "double-click" reaction. Polymer Chemistry. 2013;4(11):3236-44.

[95] Engler AC, Ke XY, Gao SJ, Chan JMW, Coady DJ, Ono RJ, et al. Hydrophilic Polycarbonates: Promising Degradable Alternatives to Poly(ethylene glycol)-Based Stealth Materials. Macromolecules. 2015;48(6):1673-8 .

[96] II-Doo K, Chae-Moon L, Jung-Bin K, Hye Yeong N, Kihoon N, Seung-Woo K, et al. Neuroprotection by biodegradable PAMAM ester (e-PAM-R)-mediated HMGB1 siRNA delivery in primary cortical cultures and in the postischemic brain. Journal of controlled release : official journal of the Controlled Release Society. 2010;142(3):422-30 .

[97] Kim ID, Shin JH, Kim SW, Choi S, Ahn J, Han PL, et al. Intranasal Delivery of HMGB1 siRNA Confers Target Gene Knockdown and Robust Neuroprotection in the Postischemic Brain. Molecular Therapy. 2012;20(4):829-39.

[98] Liu C, Liu XX, Rocchi P, Qu FQ, lovanna JL, Peng L. Arginine- Terminated Generation 4 PAMAM Dendrimer as an Effective Nanovector for Functional siRNA Delivery in Vitro and in Vivo. Bioconjugate Chemistry. 2014;25(3):521-32 .

INSTITUTO DE INVESTİGAÇÃO E INOVAÇA UNIVERSIDADE UNIVERSIDAD

Rua Alfredo Allen, 208 4200-135 Porto 
[99] Tsutsumi T, Hirayama F, Uekama K, Arima H. Evaluation of polyamidoamine dendrimer/alphacyclodextrin conjugate (generation $3, G_{3}$ ) as a novel carrier for small interfering RNA (siRNA). Journal of Controlled Release. 2007;119(3):349-59.

[100] Arima H, Tsutsumi T, Yoshimatsu A, Ikeda H, Motoyama K, Higashi T, et al. Inhibitory effect of siRNA complexes with polyamidoamine dendrimer/alpha-cyclodextrin conjugate (generation $3, G_{3}$ ) on endogenous gene expression. European Journal of Pharmaceutical Sciences. 2011;44(3):375-84 .

[101] Arima H, Yoshimatsu A, Ikeda H, Ohyama A, Motoyama K, Higashi T, et al. Folate-PEGappended dendrimer conjugate with alphacyclodextrin as a novel cancer cell-selective siRNA delivery carrier. Mol Pharm. 2012;9(9):2591-604.

[102] Hayashi Y, Mori Y, Higashi T, Motoyama K, Jono H, Sah DW, et al. Systemic delivery of transthyretin siRNA mediated by lactosylated dendrimer/alpha-cyclodextrin conjugates into hepatocyte for familial amyloidotic polyneuropathy therapy. Amyloid : the international journal of experimental and clinical investigation : the official journal of the International Society of Amyloidosis. 2012;19 Suppl 1:47-9.

[103] Ohyama A, Higashi T, Motoyama K, Arima H. In Vitro and In Vivo Tumor-Targeting siRNA Delivery Using Folate-PEG-appended Dendrimer (G4)/alpha-Cyclodextrin Conjugates. Bioconjug Chem. 2016;27(3):521-32 .

[104] Baigude H, McCarroll J, Yang CS, Swain PM, Rana TM. Design and creation of new nanomaterials for therapeutic RNAi. Acs Chem Biol. 2007;2(4):237-41 .

[105] Patil ML, Zhang M, Betigeri S, Taratula O, He H, Minko T. Surface- modified and internally cationic polyamidoamine dendrimers for efficient siRNA delivery. Bioconjugate Chemistry. 2008; 19(7): 1396-403 .

[106] Khan OF, Zaia EW, Yin H, Bogorad RL, Pelet JM, Webber MJ, et al. Ionizable amphiphilic dendrimer-based nanomaterials with alkyl- chain-substituted amines for tunable siRNA delivery to the liver endothelium in vivo. Angew Chem Int Ed Engl. 2014; 53(52):14397-401 .

[107] Khan OF, Zaia EW, Jhunjhunwala S, Xue W, Cai W, Yun DS, et al. Dendrimer-Inspired Nanomaterials for the in Vivo Delivery of siRNA to Lung Vasculature. Nano Lett. 2015;15(5):3008-16.

[108] Ma D. Enhancing endosomal escape for nanoparticle mediated siRNA delivery. Nanoscale. 2014;6(12):6415-25

[109] Shen XC, Zhou J, Liu X, Wu J, Qu F, Zhang ZL, et al. Importance of size-to-charge ratio in construction of stable and uniform nanoscale RNA/dendrimer complexes. Organic \& biomolecular chemistry. 2007;5(22):3674-81.

[110] Xiao---xuan L, Palma R, Fan---qi Q, Shu---quan Z, Zi---cai L, Martin G, et al. PAMAM Dendrimers Mediate siRNA Delivery to Target Hsp27 and Produce Potent Antiproliferative Effects on Prostate Cancer Cells. Chemmedchem. 2009;4(8):1302-10 .

[111] Agrawal A, Min DH, Singh N, Zhu H, Birjiniuk A, von Maltzahn G, et al. Functional delivery of siRNA in mice using dendriworms. ACS Nano. 2009;3(9):2495-504 .

INSTITUTO DE INVESTIGGÇÃO E INOVAÇA UNIVERSIDADE DO PORTO

Rua Alfredo Allen, 208 4200-135 Porto 
[112] Rodrigo AC, Rivilla I, Perez-Martinez FC, Monteagudo S, Ocana V, Guerra J, et al. Efficient, nontoxic hybrid PPV-PAMAM dendrimer as a gene carrier for neuronal cells. Biomacromolecules. 2011;12(4):1205-13.

[113] Zhou J, Neff CP, Liu X, Zhang J, Li H, Smith DD, et al. Systemic administration of combinatorial dsiRNAs via nanoparticles efficiently suppresses HIV-1 infection in humanized mice. Molecular therapy : the journal of the American Society of Gene Therapy. 2011;19(12):2228-38 .

[114] Liu X, Liu C, Laurini E, Posocco P, Pricl S, Qu F, et al. Efficient delivery of sticky siRNA and potent gene silencing in a prostate cancer model using a generation 5 triethanolamine-core PAMAM dendrimer. Mol Pharm. 2012;9(3):470-81.

[115] Kala S, Mak AS, Liu X, Posocco P, Pricl S, Peng L, et al. Combination of dendrimer-nanovectormediated small interfering RNA delivery to target Akt with the clinical anticancer drug paclitaxel for effective and potent anticancer activity in treating ovarian cancer. Journal of medicinal chemistry. 2014; $57(6): 2634-42$.

[116] Yu TZ, Liu XX, Bolcato-Bellemin AL, Wang Y, Liu C, Erbacher P, et al. An Amphiphilic Dendrimer for Effective Delivery of Small Interfering RNA and Gene Silencing In Vitro and In Vivo. Angew Chem Int Edit. 2012;51(34):8478-84.

[117] Tschiche A, Staedtler AM, Malhotra S, Baver H, Bottcher C, Sharbati S, et al. Polyglycerol-based amphiphilic dendrons as potential siRNA carriers for in vivo applications. Journal of Materials Chemistry B. 2014;2(15):2153-67.

[118] Kang HM, DeLong R, Fisher MH, Juliano RL. Tat-conjugated PAMAM dendrimers as delivery agents for antisense and siRNA oligonucleotides. Pharm Res. 2005;22(12):2099-106.

[119] Bi XD, Shi XY, Baker JR. Synthesis, characterization and stability of a luteinizing hormonereleasing hormone (LHRH)- functionalized poly(amidoamine) dendrimer conjugate. J Biomat SciPolym E. 2008;19(1):131-42 .

[120] Waite CL, Roth CM. PAMAM-RGD Conjugates Enhance siRNA Delivery Through a Multicellular Spheroid Model of Malignant Glioma. Bioconjugate Chemistry. 2009;20(10):1908-16 .

[121] Taratula O, Garbuzenko OB, Kirkpatrick P, Pandya I, Savla R, Pozharov VP, et al. Surfaceengineered targeted PPI dendrimer for efficient intracellular and intratumoral siRNA delivery. Journal of controlled release : official journal of the Controlled Release Society. 2009;140(3):284-93 .

[122] Taratula O, Garbuzenko O, Savla R, Wang YA, He HX, Minko T. Multifunctional Nanomedicine Platform for Cancer Specific Delivery of siRNA by Superparamagnetic Iron Oxide NanoparticlesDendrimer Complexes. Curr Drug Deliv. 2011;8(1):59-69.

[123] Li G, Hu Z, Yin H, Zhang Y, Huang X, Wang $S$, et al. A novel dendritic nanocarrier of polyamidoamine-polyethylene glycolcyclic RGD for "smart" small interfering RNA delivery and in vitro antitumor effects by human ether-a-go-go-related gene silencing in anaplastic thyroid carcinoma cells. Int J Nanomedicine. 2013;8:1293-306.

[124] Jain K, Kesharwani P, Gupta U, Jain NK. Dendrimer toxicity: let's meet the challenge. International Journal of Pharmaceutics. 2010; 394(1-2):122-42 .

INSTITUTO DE INVESTIGGACÃO EINOVAÇA UNIVERSIDADE UNIVERSIDAD

Rua Alfredo Allen, 208 4200-135 Porto 
[125] Leiro V, Garcia JP, Tomas H, Pego AP. The Present and the Future of Degradable Dendrimers and Derivatives in Theranostics. Bioconjugate Chemistry. 2015;26(7):1182-97 .

[126] Malik N, Evagorou EG, Duncan R. Dendrimer-platinate: a novel approach to cancer chemotherapy. Anticancer Drugs. 1999; 10(8): 767-76.

[127] Leiro V, Garcia JP, Moreno PMD, Spencer AP, Fernandez- Villamarin M, Riguera R, FernandezMegia E, Pego AP. Biodegradable PEG-dendritic block copolymers: synthesis and biofunc tionality assessment as vectors of siRNA. Journal of Materials Chemistry B. 2017. 10.1039/c7tboo279c.

[128] Park JH, von Maltzahn G, Zhang L, Derfus AM, Simberg D, Harris TJ, et al. Systematic surface engineering of magnetic nanoworms for in vivo tumor targeting. Small. 2009;5(6):694-700 .

[129] Liu C, Liu X, Rocchi P, Qu F, lovanna JL, Peng L. Arginineterminated generation 4 PAMAM dendrimer as an effective nanovector for functional siRNA delivery in vitro and in vivo. Bioconjug Chem. 2014;25(3):521-32.

[130] Yu T, Liu X, Bolcato-Bellemin AL, Wang Y, Liu C, Erbacher P, et al. An amphiphilic dendrimer for effective delivery of small interfering RNA and gene silencing in vitro and in vivo. Angew Chem Int Ed Engl. 2012;51(34):8478-84 .

[131] Serramia MJ, Alvarez S, Fuentes-Paniagua E, Clemente MI, Sanchez- Nieves J, Gomez R, et al. In vivo delivery of siRNA to the brain by carbosilane dendrimer. Journal of controlled release: official journal of the Controlled Release Society. 2015; 200: 60-70. 2015/01/07.

[132] Mignani S, El Kazzouli S, Bousmina M, Majoral JP. Expand classical drug administration ways by emerging routes using dendrimer drug delivery systems: A concise overview. Adv Drug Deliv Rev. 2013;65(10):1316-30 .

[133] Kim ID, Lim CM, Kim JB, Nam HY, Nam K, Kim SW, et al. Neuroprotection by biodegradable PAMAM ester (e-PAM-R)- mediated HMGB1 siRNA delivery in primary cortical cultures and in the postischemic brain. Journal of controlled release : official journal of the Controlled Release Society. 2010;142(3):422-30. 2009/12/01.

[134] Tang Y, Li YB, Wang B, Lin RY, van Dongen M, Zurcher DM, et al. Efficient in vitro siRNA delivery and intramuscular gene silencing using PEG-modified PAMAM dendrimers. Mol Pharm. 2012;9(6):1812-21.

[135] Perez AP, Mundina-Weilenmann C, Romero EL, Morilla MJ. Increased brain radioactivity by intranasal P-labeled siRNA dendriplexes within in situ-forming mucoadhesive gels. Int J Nanomedicine. 2012;7:1373-85 .

[136] Kim ID, Shin JH, Kim SW, Choi S, Ahn J, Han PL, et al. Intranasal delivery of HMGB1 siRNA confers target gene knockdown and robust neuroprotection in the postischemic brain. Molecular therapy: the journal of the American Society of Gene Therapy. 2012;20(4):829-39 .

[137] Liu J, Gu C, Cabigas EB, Pendergrass KD, Brown ME, Luo Y, et al. Functionalized dendrimerbased delivery of angiotensin type 1 receptor siRNA for preserving cardiac function following infarction. Biomaterials. 2013;34(14):3729-36.

INSTITUTO DE INVESTİGAÇÃO E INOVAÇA UNIVERSIDADE UNIVERSIDAD

Rua Alfredo Allen, 208 4200-135 Porto 
[138] Liu XX, Zhou JH, Yu TZ, Chen C, Cheng Q, Sengupta K, et al. Adaptive Amphiphilic DendrimerBased Nanoassemblies as Robust and Versatile siRNA Delivery Systems. Angew Chem Int Edit. 2014;53(44):11822-7.

[139] Liu XX, Liu C, Chen C, Bentobji M, Cheillan FA, Piana JT, et al. Targeted delivery of Dicersubstrate siRNAs using a dual targeting peptide decorated dendrimer delivery system. NanomedNanotechnol. 2014;10(8):1627-36.

[140] Zheng W, Cao C, Liu Y, Yu Q, Zheng C, Sun D, et al. Multifunctional polyamidoamine-modified selenium nanoparticles dualdelivering siRNA and cisplatin to A549/DDP cells for reversal multidrug resistance. Acta biomaterialia. 2015;11:368-80.

[141] Li J, Liu J, Li S, Hao Y, Chen L, Zhang X. Antibody h-R3- dendrimer mediated siRNA has excellent endosomal escape and tumor targeted delivery ability, and represents efficient siPLK1 silencing and inhibition of cell proliferation, migration and invasion. Oncotarget. 2016.

[142] Shah V, Taratula O, Garbuzenko OB, Taratula OR, Rodriguez- Rodriguez L, Minko T. Targeted nanomedicine for suppression of $\mathrm{CD}_{4} 4$ and simultaneous cell death induction in ovarian cancer: an optimal delivery of siRNA and anticancer drug. Clinical cancer research : an official journal of the American Association for Cancer Research. 2013;19(22):6193-204.

[143] Watanabe K, Harada-Shiba M, Suzuki A, Gokuden R, Kurihara R, Sugao Y, et al. In vivo siRNA delivery with dendritic poly(Llysine) for the treatment of hypercholesterolemia. Molecular bioSystems. 2009;5(11):1306-10.

[144] Baigude H, Su J, McCarroll J, Rana TM. In Vivo Delivery of RNAi by Reducible Interfering Nanoparticles (iNOPs). ACS medicinal chemistry letters. 2013;4(8):720-3.

[145] Hayashi Y, Mori Y, Yamashita S, Motoyama K, Higashi T, Jono $H$, et al. Potential use of lactosylated dendrimer ( $\left.\mathrm{G}_{3}\right)$ /alphacyclodextrin conjugates as hepatocyte-specific siRNA carriers for the treatment of familial amyloidotic polyneuropathy. Mol Pharm. 2012;9(6):1645-53 .

[146] Malik N, Wiwattanapatapee R, Klopsch R, Lorenz K, Frey H, Weener JW, et al. Dendrimers: relationship between structure and biocompatibility in vitro, and preliminary studies on the biodistribution of 125 l-labelled polyamidoamine dendrimers in vivo. Journal of controlled release : official journal of the Controlled Release Society. 2000;65(1-2):133-48 .

[147] Maeda H, Fang J, Inutsuka T, Kitamoto Y. Vascular permeability enhancement in solid tumor: various factors, mechanisms involved and its implications. International immunopharmacology. 2003; 3(3): 319-28.

[148] Bugno J, Hsu HJ, Pearson RM, Noh H, Hong S. Size and Surface Charge of Engineered Poly(amidoamine) Dendrimers Modulate Tumor Accumulation and Penetration: A Model Study Using Multicellular Tumor Spheroids. Mol Pharm. 2016.

[149] Pardridge WM. The blood-brain barrier: bottleneck in brain drug development. NeuroRx : the journal of the American Society for Experimental NeuroTherapeutics. 2005;2(1):3-14 .

[150] Somani S, Blatchford DR, Millington O, Stevenson ML, Dufes C. Transferrin-bearing polypropylenimine dendrimer for targeted gene delivery to the brain. Journal of controlled release: official journal of the Controlled Release Society. 2014;188:78-86.

INSTITUTO DE INVESTIGGAÇÃO EINOVAÇA UNIVERSIDADE UNIVERSIDAD

Rua Alfredo Allen, 208 4200-135 Porto 
[151] Duncan R, Izzo L. Dendrimer biocompatibility and toxicity. Advanced drug delivery reviews. 2005; 57(15): 2215-37.

[152] Lee JH, Cha KE, Kim MS, Hong HW, Chung DJ, Ryu G, et al. Nanosized polyamidoamine (PAMAM) dendrimer-induced apoptosis mediated by mitochondrial dysfunction. Toxicology letters. 2009;190(2):202-7 .

[153] Omidi Y, Hollins AJ, Drayton RM, Akhtar S. Polypropylenimine dendrimer-induced gene expression changes: the effect of complexation with DNA, dendrimer generation and cell type. Journal of drug targeting. 2005;13(7):431-43.

[154] Okuda T, Kawakami S, Maeie T, Niidome T, Yamashita F, Hashida M. Biodistribution characteristics of amino acid dendrimers and their PEGylated derivatives after intravenous administration. Journal of controlled release: official journal of the Controlled Release Society. 2006;114(1):69-77.

[155] Albertazzi L, Gherardini L, Brondi M, Sulis Sato S, Bifone A, Pizzorusso T, et al. In vivo distribution and toxicity of PAMAM dendrimers in the central nervous system depend on their surface chemistry. Mol Pharm. 2013;10(1):249-60 .

[156] Chen C, Posocco P, Liu X, Cheng Q, Laurini E, Zhou J, et al. Mastering Dendrimer Self-Assembly for Efficient siRNA Delivery: From Conceptual Design to In Vivo Efficient Gene Silencing. Small. 2016;12(27):3667-76 .

[157] Lloyd JB. Lysosome membrane permeability: implications for drug delivery. Adv Drug Deliv Rev. 2000;41(2):189-200.

[158] Shcharbin D, Janaszewska A, Klajnert-Maculewicz B, Ziemba B, Dzmitruk V, Halets I, et al. How to study dendrimers and dendriplexes III. Biodistribution, pharmacokinetics and toxicity in vivo. Journal of controlled release : official journal of the Controlled Release Society. 2014;181:40-52

[159] Bermejo JF, Ortega P, Chonco L, Eritja R, Samaniego R, Mullner M, et al. Water-soluble carbosilane dendrimers: synthesis biocompatibility and complexation with oligonucleotides; evaluation for medical applications. Chemistry. 2007;13(2):483-95

[160] Keaney J, Campbell M, Humphries P. From RNA interference technology to effective therapy: how far have we come and how far to go? Therapeutic delivery. 2011;2(11):1395-406 .

[161] Wei P, Chen J, Hu Y, Li X, Wang H, Shen M, et al. Dendrimer- Stabilized Gold Nanostars as a Multifunctional Theranostic Nanoplatform for CT Imaging, Photothermal Therapy, and Gene Silencing of Tumors. Adv Healthc Mater. 2016; 5(24): 3203-13.

[162] Roberts CM, Shahin SA, Wen W, Finlay JB, Dong J, Wang R, et al. Nanoparticle delivery of siRNA against TWIST to reduce drug resistance and tumor growth in ovarian cancer models. Nanomedicine. 2016.

[163] Leiro V, Santos SD, Lopes CDF, Pêgo AP. Dendrimers as Powerful Building Blocks in Central Nervous System Disease: Headed for Successful Nanomedicine. Advanced Functional Materials, 2017. DOI: 10.1002/adfm.201700313. 


\section{Figures}

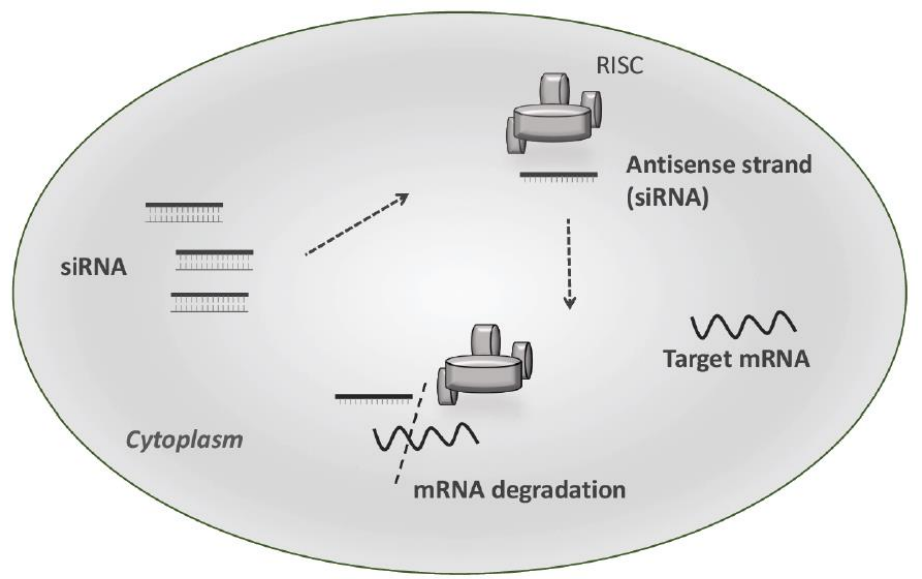

Fig. (1). RNAi mechanism of action, showing the siRNA pathway, which culminates in the downregulation of gene expression from a specific target.

a)

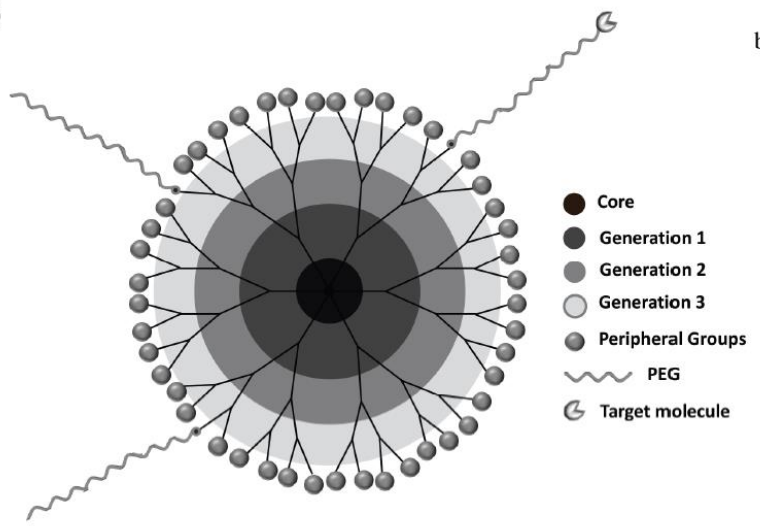

b)

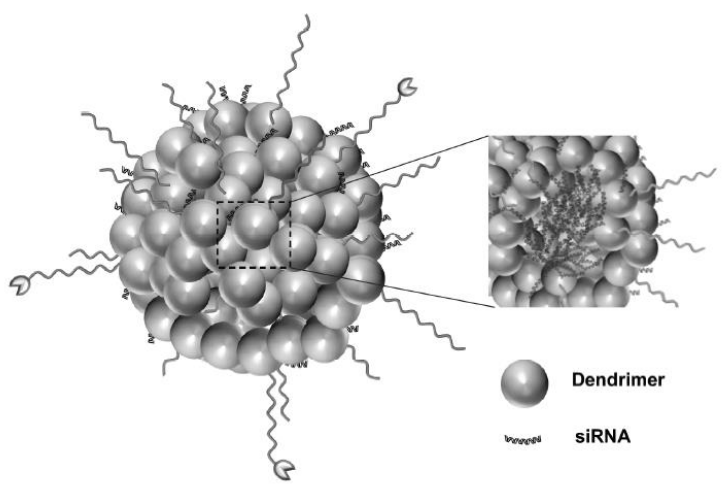

Fig. (2). Schematic representation of: a) a dendrimer with attached chains of poly(ethylene glycol) (PEG) and a target molecule, b) siRNA/dendrimer complex (dendriplex). 
Table 1. Description of distinct in vivo studies using dendrimers to deliver siRNA. The information

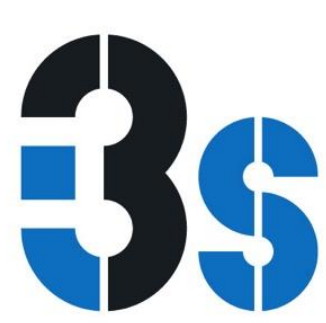
is grouped according to the dendrimer type. Abbreviations: PAMAM: poly(amidoamine); PLL: Poly(L-lysine); PPI: Poly(propylene imine); PG: Poly(glycerol); TEA: Triethanolamine; PEG: Poly(ethylene glycol); i.v.: intravenous; i.n. intranasal; i.p.: intraperitoneal; Tiez: tunica interna endothelial cell kinase; HMGB1: High-mobility group box 1; HSP27: heat shock transcription factor 27; EGFR: Epidermal growth factor receptor; ATR1: Angiotensin II type 1 receptor; ApoB: Apoliprotein B, mdr1: multidrug resistance 1; PLK1: Polo-like kinase 1; $\mathrm{BCl}_{2}$ : B-cell lymphoma 2; TTR: Transthyretin; Nef: Negative Regulatory Factor; D-siRNA: Dicer-substrate siRNA; PBMC: peripheral blood mononuclear cells.

\begin{tabular}{|c|c|c|c|c|c|c|c|c|c|}
\hline Dendrimers & Generation & siRNA & $\begin{array}{l}\text { Amount } \\
\text { SiRNA }\end{array}$ & Organism & $\begin{array}{c}\text { Route of } \\
\text { Administration }\end{array}$ & $\begin{array}{l}\text { Time of } \\
\text { Analysis }\end{array}$ & Organ & Main Outcome & Reference \\
\hline \multicolumn{10}{|c|}{ PAMAM } \\
\hline $\begin{array}{c}\text { Cystamine core, } \\
\text { PAMAM, with magnetic } \\
\text { particles }\end{array}$ & G4 & $\begin{array}{l}\text { EGFR } \\
\text { siRNA }\end{array}$ & $\begin{array}{c}0.5 \mathrm{ul} / \mathrm{h} @ \\
0.115 \mathrm{mg} / \mathrm{ml}\end{array}$ & Mice & $\begin{array}{l}\text { intracranial } \\
\text { osmotic pump }\end{array}$ & $3 \mathrm{~d} / 7 \mathrm{~d}$ & Brain tumor & $\begin{array}{l}\text { Significant sup- } \\
\text { pression of EGFR } \\
\text { expression }\end{array}$ & [111] \\
\hline $\begin{array}{l}\text { Arginine ester of } \\
\text { PAMAM }\end{array}$ & G4 & $\begin{array}{l}\text { HMGB1 } \\
\text { siRNA }\end{array}$ & $100 \mathrm{ng} / \mathrm{rat}$ & Rat & intracranial & $\begin{array}{l}12,18,24 \\
\text { and } 48 \mathrm{~h}\end{array}$ & Brain & $\begin{array}{l}\text { HMGBI knock- } \\
\text { down in the cor- } \\
\text { tex, persistent for } \\
48 \mathrm{~h}\end{array}$ & [133] \\
\hline TEA-core PAMAMr & G5 & $\begin{array}{l}\text { HIV } \\
\text { tatirev, } \\
\text { CD4 and } \\
\text { TNPO3 } \\
\text { siRNA }\end{array}$ & $\begin{array}{c}5 \times 0.25 \\
\text { nmol/mice. }+ \\
2 \times 0.25 \\
\text { nmol } / \text { mice }\end{array}$ & Mice & iv. & $\begin{array}{l}2 \mathrm{w} / 1-20 \\
\mathrm{w} / 2,24 \mathrm{~h}\end{array}$ & Liver, blood & $\begin{array}{l}\text { siRNA in PBMC } \\
\text { and liver. Inhibi- } \\
\text { tion of HIV-1 } \\
\text { infection }\end{array}$ & [113] \\
\hline Amphiphilic PAMAM & G3 & $\begin{array}{l}\text { Hsp27 } \\
\text { siRNA }\end{array}$ & $4 \times 1 \mathrm{mg} / \mathrm{kg}$ & Mice & intratumoral & $6 \mathrm{~d}$ & Tumor & $\begin{array}{l}\text { Down regulation } \\
\text { of Hsp } 27 \text { and } \\
\text { inhibition of tumor } \\
\text { growth }\end{array}$ & [130] \\
\hline PEG-modified PAMAM & G5 and G6 & $\begin{array}{c}\text { GFP } \\
\text { siRNA }\end{array}$ & $\begin{array}{c}120 \text { and } 240 \\
\text { pmol }\end{array}$ & Mice & intramuscular & $48 \mathrm{~h}, 72 \mathrm{~h}$ & $\begin{array}{l}\text { Quadriceps } \\
\text { muscle }\end{array}$ & $\begin{array}{c}\text { Decreased GFP } \\
\text { expression }\end{array}$ & [134] \\
\hline TEA-core PAMAM & G5 & $\begin{array}{l}\text { Hsp27 } \\
\text { siRNA }\end{array}$ & $2 \times 3 \mathrm{mg} / \mathrm{kg}$ & Mice & intratumoral & 1 week & Tumor & $\begin{array}{l}\text { Decreased Hsp27 } \\
\text { expression and } \\
\text { inhibition of tumor } \\
\text { cell proliferation }\end{array}$ & [114] \\
\hline $\begin{array}{l}\text { Folate-PEG-appended } \\
\text { PAMAM with } \alpha- \\
\text { cyclodextrin }\end{array}$ & G3 & $\begin{array}{l}\text { Firefly } \\
\text { luciferase } \\
\text { siRNA, } \\
\text { FITC } \\
\text { siRNA }\end{array}$ & 10 and $50 \mathrm{ug}$ & Mice & $\begin{array}{l}\text { intratumoral and } \\
\text { iv. }\end{array}$ & $24 \mathrm{~h}, 0-5 \mathrm{~h}$ & $\begin{array}{l}\text { Tumor, } \\
\text { blood, liver, } \\
\text { heart, kid- } \\
\text { ney, spleen, } \\
\text { lung }\end{array}$ & $\begin{array}{l}\text { Reduced luciferase } \\
\text { activity. FITC } \\
\text { accumulation in } \\
\text { kidney and tumor. } \\
\text { No toxicity. }\end{array}$ & [101] \\
\hline $\begin{array}{l}\text { PAMAM in polox- } \\
\text { amer/carbopol gel }\end{array}$ & G7 & ${ }^{32} \mathrm{p}$-siRNA & $\begin{array}{c}2 \times 28 \\
\text { pmol/rat }\end{array}$ & Rat & in. andi.v. & $\begin{array}{l}90 / 180 \\
\text { minutes }\end{array}$ & Brain, blood & $\begin{array}{c}\text { Radioactivity } \\
\text { foumd in blood and } \\
\text { olfactory bulb }\end{array}$ & [135] \\
\hline $\begin{array}{l}\text { Arginine ester of } \\
\text { PAMAM }\end{array}$ & $\mathrm{G} 4$ & $\begin{array}{l}\text { HMGB1 } \\
\text { siRNA }\end{array}$ & $2 \mathrm{ug} / \mathrm{rat}$ & Rat & in. & $3,12,24 \mathrm{~h}$ & Brain & $\begin{array}{l}\text { HMGBI knock- } \\
\text { down in the } \\
\text { amygdala, hypo- } \\
\text { thalamus, cortex } \\
\text { and striatum }\end{array}$ & [136] \\
\hline $\begin{array}{l}\text { Oligo-arginine couju- } \\
\text { gated PAMAM }\end{array}$ & $\mathrm{G} 4$ & $\begin{array}{l}\text { ATRl } \\
\text { siRNA }\end{array}$ & $5 \mathrm{ug} / \mathrm{kg}$ & Rat & $\begin{array}{l}\text { intramyocardial } \\
\text { injection }\end{array}$ & $3 d$ & Heart & $\begin{array}{l}\text { No increase in } \\
\text { ATR1 after infarc- } \\
\text { tion and improved } \\
\text { cardiac fumction }\end{array}$ & [137] \\
\hline TEA-core PAMAM & G6 & $\begin{array}{c}\text { Alkt } \\
\text { siRNA }\end{array}$ & $0.625 \mathrm{mg} / \mathrm{kg}$ & Mice & intratumoral & 1 week & Tumor & $\begin{array}{l}\text { Enhanced cancer } \\
\text { cell apoptosis } \\
\text { when Alkt siRNA } \\
\text { is administered } \\
\text { with paclitaxel }\end{array}$ & [115] \\
\hline
\end{tabular}

(Table 1) contd...

Version: Postprint (identical content as published paper) This is a self-archived document from i3S - Instituto de Investigação e Inovação em Saúde in the University of Porto Open Repository For Open Access to more of our 


\begin{tabular}{|c|c|c|c|c|c|c|c|c|c|}
\hline Dendrimers & Generation & siRNA & $\begin{array}{l}\text { Amount } \\
\text { siRNA }\end{array}$ & Organism & $\begin{array}{c}\text { Route of } \\
\text { Administration }\end{array}$ & $\begin{array}{l}\text { Time of } \\
\text { Analysis }\end{array}$ & Organ & Main Outcome & Reference \\
\hline \multicolumn{10}{|c|}{ PAMAM } \\
\hline $\begin{array}{l}\text { PAMAM and PPI modi- } \\
\text { fied with allsyl chains }\end{array}$ & $\mathrm{Gl}$ & $\begin{array}{c}\text { Tie2 and } \\
\text { Factor VII } \\
\text { siRNA }\end{array}$ & $\begin{array}{c}1 \mathrm{mg} / \mathrm{kg} \\
(\text { Tie2) }+125 \\
\text { ug } / \mathrm{kg}(\mathrm{FVI})\end{array}$ & Mice & i.v. & $2 \mathrm{~d}$ & Liver, blood & $\begin{array}{l}\text { Nanoparticles } \\
\text { affinity for the } \\
\text { liver. Decreased } \\
\text { tie2 and FVII } \\
\text { expression. }\end{array}$ & [106] \\
\hline $\begin{array}{l}\text { Arginine-terminated } \\
\text { TEA-core PAMAM }\end{array}$ & G4 & $\begin{array}{l}\text { Hsp27 } \\
\text { siRNA }\end{array}$ & $4 \times 3 \mathrm{mg} / \mathrm{kg}$ & Mice & intratumoral & 2 weeks & Tumor & $\begin{array}{l}\text { Effective gene } \\
\text { silencing and } \\
\text { decreased cancer } \\
\text { cell proliferation }\end{array}$ & [129] \\
\hline Amphiphilic PAMAM & G3 & $\begin{array}{l}\text { Hsp27 } \\
\text { siRNA }\end{array}$ & $10 \times 3 \mathrm{mg} / \mathrm{kg}$ & Mice & i.p. & 5 weeks & Tumor & $\begin{array}{c}\text { Down-regulation } \\
\text { of Hsp27 and } \\
\text { inhibition of tumor } \\
\text { growth }\end{array}$ & [138] \\
\hline TEA-core PAMAM & G5 & $\begin{array}{l}\text { Hsp27 D- } \\
\text { siRNA }\end{array}$ & $8 \mathrm{x} 3 \mathrm{mg} / \mathrm{kg}$ & Mice & ip. & 4 weeks & Tumor & $\begin{array}{l}\text { Superior gene } \\
\text { silencing and } \\
\text { tumor growth } \\
\text { inhibition. }\end{array}$ & [139] \\
\hline $\begin{array}{l}\text { PAMAM modified with } \\
\text { selenimm }\end{array}$ & G5 & $\begin{array}{c}\text { mdrl } \\
\text { saRNA }\end{array}$ & $14 \mathrm{x} 2.5 \mathrm{mg} \mathrm{kg}$ & Mice & intratumoral & $15 \mathrm{~d}$ & $\begin{array}{c}\text { Tumor, } \\
\text { beart, liver, } \\
\text { spleen, } \\
\text { hung, kidney }\end{array}$ & $\begin{array}{l}\text { The dual delivery } \\
\text { of siRNA and } \\
\text { cisplatin enhanced } \\
\text { the anti-tumor } \\
\text { effect }\end{array}$ & [140] \\
\hline $\begin{array}{l}\text { PAMAM and PPI } \\
\text { (modified with Epoxide- } \\
\text { terminated allsyl chains) }\end{array}$ & $\mathrm{Gl}$ & $\begin{array}{c}\text { Tie2 } 2 \\
\text { saRNA }\end{array}$ & $\begin{array}{c}2.5,1 \text { and } 0.5 \\
\mathrm{mg} / \mathrm{kg}\end{array}$ & Mice & i.v. & $1 \mathrm{~h} / 2 \mathrm{~d} / 3 \mathrm{~d}$ & Lung & $\begin{array}{c}\text { Decreased Tie2 } \\
\text { mRNA }\end{array}$ & [107] \\
\hline $\begin{array}{c}\text { Ethylenediamine core } \\
\text { PAMAM }\end{array}$ & G5 & $\begin{array}{l}\text { Cy5- } \\
\text { siRNA }\end{array}$ & Not described & Mice & i.v. & $24 \mathrm{~h}$ & $\begin{array}{c}\text { Tumor, } \\
\text { heart, liver, } \\
\text { spleen, } \\
\text { hung, kidney }\end{array}$ & $\begin{array}{l}\text { Increased denctri- } \\
\text { plex accumulation } \\
\text { in tumor }\end{array}$ & [141] \\
\hline $\begin{array}{l}\text { Folate-PEG-appended } \\
\text { PAMAM with } \alpha- \\
\text { cyclodextrin }\end{array}$ & G4 & $\begin{array}{l}\text { saRNA } \\
\text { PLK1 }\end{array}$ & 50 ugminice & Mice & i.v. & $\begin{array}{c}24 \mathrm{~h}, 0- \\
20 \mathrm{~d}\end{array}$ & $\begin{array}{l}\text { Blood, } \\
\text { tumor }\end{array}$ & $\begin{array}{l}\text { Improved blood } \\
\text { circulation and } \\
\text { RNAi effect. } \\
\text { Suppressed tumor } \\
\text { growth }\end{array}$ & [103] \\
\hline \multicolumn{10}{|c|}{ PPI } \\
\hline PPI & G5 & $\begin{array}{l}\mathrm{BCL} 2 \\
\text { saRNA }\end{array}$ & $1.9 \mathrm{mg} / \mathrm{kg}$ & Mice & i.v. & $72 \mathrm{~h}$ & Tumor & $\begin{array}{c}\text { Preferential siRNA } \\
\text { localization in } \\
\text { tumor }\end{array}$ & [121] \\
\hline PPI & G5 & $\begin{array}{l}\text { CD44 } \\
\text { siRNA }\end{array}$ & $8 \times 2.5 \mathrm{mg} / \mathrm{kg}$ & Mice & i.p. & $\begin{array}{l}48 \mathrm{~h}, 0- \\
28 \mathrm{~d}\end{array}$ & $\begin{array}{l}\text { Tumor, } \\
\text { liver, kid- } \\
\text { ney, spleen, } \\
\text { beart, lung. } \\
\text { brain }\end{array}$ & $\begin{array}{l}\text { Increased tumor } \\
\text { apoptosis and } \\
\text { higher activity of } \\
\text { siRNA when using } \\
\text { paclitasel. }\end{array}$ & [142] \\
\hline \multicolumn{10}{|c|}{ PLL dendrimers } \\
\hline PLL & Go & $\begin{array}{l}\text { ApoB } \\
\text { siRNA }\end{array}$ & $\begin{array}{c}2.5 \mathrm{mg} / \mathrm{kg} .1 .5 \\
\mathrm{mg} / \mathrm{kg}\end{array}$ & Mice & i.v. & $\begin{array}{c}24 \mathrm{~h} / 24- \\
96 \mathrm{~h}\end{array}$ & Liver, blood & $\begin{array}{l}\text { Decreased ApoB } \\
\text { expression }\end{array}$ & [143] \\
\hline $\begin{array}{l}\text { PLI modified with } \\
\text { reducible spacers }\end{array}$ & $\begin{array}{l}\text { Not de- } \\
\text { scribed }\end{array}$ & $\begin{array}{l}\text { ApoB } \\
\text { siRNA }\end{array}$ & $1 \mathrm{mg} / \mathrm{kg}$ & Mice & i.v. & $24 \mathrm{~h}, 48 \mathrm{~h}$ & $\begin{array}{l}\text { Liver, } \\
\text { spleen, } \\
\text { lidiney. } \\
\text { blood }\end{array}$ & $\begin{array}{l}\text { Decreased Apo B } \\
\text { in liver and blood }\end{array}$ & [144] \\
\hline
\end{tabular}

ÇÃo

E 


\begin{tabular}{|c|c|c|c|c|c|c|c|c|c|}
\hline Dendrimers & Generation & siRNA & $\begin{array}{l}\text { Amount } \\
\text { siRNA }\end{array}$ & Organism & $\begin{array}{c}\text { Route of } \\
\text { Administration }\end{array}$ & $\begin{array}{l}\text { Time of } \\
\text { Analysis }\end{array}$ & Organ & Main Outcome & Reference \\
\hline \multicolumn{10}{|c|}{ Other Dendrimers } \\
\hline Triazine & G2 & $\begin{array}{l}\text { Labeled } \\
\text { siRNA, } \\
\text { Firefly } \\
\text { luciferase } \\
\text { DsiRNA }\end{array}$ & $35 \mu \mathrm{g} /$ mice & Mice & i.v. & $2 \mathrm{~h}, 24 \mathrm{~h}$ & $\begin{array}{l}\text { Blood, lung, } \\
\text { liver, blad- } \\
\text { der }\end{array}$ & $\begin{array}{l}\text { Dendriplexes } \\
\text { stable in serum, } \\
\text { siRNA presence in } \\
\text { liver and lung }\end{array}$ & [47] \\
\hline $\begin{array}{l}\text { Lactosylated dendrimer } \\
\text { conjugated with } \alpha \text { - } \\
\text { cyclodextrin }\end{array}$ & G3 & $\begin{array}{c}\text { TTR } \\
\text { siRNA }\end{array}$ & $\begin{array}{c}1 \mathrm{mg} / \mathrm{kg}, 9 \\
\mathrm{mg} / \mathrm{kg}\end{array}$ & Mice & i.v. & $48 \mathrm{~h}$ & Liver & $\begin{array}{l}\text { Decreased TTR } \\
\text { mRNA }\end{array}$ & [145] \\
\hline $\begin{array}{l}\text { PG-based amphiphilic } \\
\text { ester-bridged dendrons }\end{array}$ & $\mathrm{G} 1$ and $\mathrm{G} 2$ & $\begin{array}{l}\text { Non- } \\
\text { targeting } \\
\text { siRNA }\end{array}$ & $\begin{array}{c}8 \mathrm{mg} / \mathrm{kg}, 20 \\
\mathrm{mg} / \mathrm{kg}\end{array}$ & Mice & i.v. & $1 \mathrm{~h}$ & Serum & $\begin{array}{l}\text { Cytokine levels in } \\
\text { the serum were not } \\
\text { elevated }\end{array}$ & [117] \\
\hline Carbosilane & G2 & $\begin{array}{l}\text { siRNA } \\
\text { NEF }\end{array}$ & $\begin{array}{c}0,54 \\
\text { nmol/mice }\end{array}$ & Mice & $\begin{array}{l}\text { retro-orbital } \\
\text { injection }\end{array}$ & $1 \mathrm{~h}, 24 \mathrm{~h}$ & $\begin{array}{l}\text { Brain, } \\
\text { spleen, and } \\
\text { liver }\end{array}$ & $\begin{array}{l}\text { Accumulation of } \\
\text { siRNA in brain, } \\
\text { spleen and liver }\end{array}$ & [131] \\
\hline $\begin{array}{l}\text { 2-(acryloyloxy)ethyl } \\
\text { methacrylate }\end{array}$ & G1-G4 & $\begin{array}{l}\text { Factor VII } \\
\text { siRNA }\end{array}$ & $1,3,4 \mathrm{mg} / \mathrm{kg}$ & Mice & i.v. & $\begin{array}{l}24 \mathrm{~h}, 48 \mathrm{~h}, \\
3 \mathrm{~d}\end{array}$ & $\begin{array}{c}\text { Blood, } \\
\text { kidney, } \\
\text { liver, spleen }\end{array}$ & $\begin{array}{l}\text { High accumulation } \\
\text { in tumor liver } \\
\text { cells, suppression } \\
\text { of Factor VII } \\
\text { expression }\end{array}$ & [87] \\
\hline
\end{tabular}

